\title{
Potential of Tailing Deposits in Chile for the Sequestration of Carbon Dioxide Produced by Power Plants Using Ex-Situ Mineral Carbonation
}

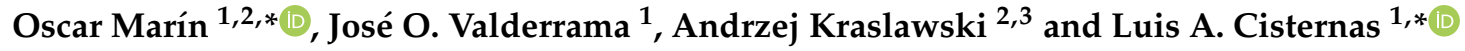 \\ 1 Departamento de Ingeniería Química y Procesos de Minerales, Universidad de Antofagasta, \\ 1240000 Antofagasta, Chile; joseovalderrama@gmail.com \\ 2 School of Engineering Science, Lappeenranta-Lahti University of Technology (LUT University), \\ FI-53851 Lappeenranta, Finland; andrzej.kraslawski@lut.fi \\ 3 Faculty of Process and Environmental Engineering, Lodz University of Technology, ul. Wolczanska 213, \\ 90-924 Lodz, Poland \\ * Correspondence: oscar.marin.cortes@lut.fi (O.M.); luis.cisternas@uantof.cl (L.A.C.)
}

check for

updates

Citation: Marín, O.; Valderrama, J.O.; Kraslawski, A.; Cisternas, L.A.

Potential of Tailing Deposits in Chile for the Sequestration of Carbon Dioxide Produced by Power Plants Using Ex-Situ Mineral Carbonation. Minerals 2021, 11, 320. https:// doi.org/10.3390/min11030320

Academic Editors: Mamadou Fall and Tuncel M. Yegulalp

Received: 14 January 2021

Accepted: 17 March 2021

Published: 19 March 2021

Publisher's Note: MDPI stays neutral with regard to jurisdictional claims in published maps and institutional affiliations.

Copyright: (c) 2021 by the authors. Licensee MDPI, Basel, Switzerland. This article is an open access article distributed under the terms and conditions of the Creative Commons Attribution (CC BY) license (https:/ / creativecommons.org/licenses/by/ $4.0 /)$.
Abstract: In this study, the potential of copper tailing deposits in Chile for the sequestration of carbon dioxide $\left(\mathrm{CO}_{2}\right)$ via ex-situ mineral carbonation integrating the recovery of valuable metals was assessed. An inventory of tailing deposits and $\mathrm{CO}_{2}$ sources existing in Chile was constructed to determine the most suitable site for the installation of a future mineral carbonation plant and to evaluate the technical, economic, and environmental feasibility of $\mathrm{CO}_{2}$ capture, separation, and transport from the source to the mineral carbonation plant. The data of the inventory of tailings deposits in Chile were obtained from the National Service of Geology and Mining. For the thermoelectric plants installed in Chile, data of energy production were obtained from the Energy National Commission. Through the use of the technique for order preference by similarity to ideal solution (TOPSIS) method and sensitivity analysis, the optimum location in the region of Antofagasta to install a mineral carbonation plant was identified. In addition, the results show that in the region of Antofagasta five tailing deposits have the potential to sequester between 66 to $99 \mathrm{Mt}$ of $\mathrm{CO}_{2}$. Meanwhile, thermoelectric plants in 2018 produced about $9.4 \mathrm{Mt}$ of $\mathrm{CO}_{2}$ that is available to be sequestered, with a maximum generation potential of $21.9 \mathrm{Mt}$ of $\mathrm{CO}_{2 \text { eq }}$ per year. The methodology and the study presented can be considered as a preliminary study to identify tailings that require further analysis.

Keywords: mine tailing deposits; $\mathrm{CO}_{2}$ sequestration; mineral carbonation; mining waste

\section{Introduction}

The release of large amounts of greenhouse gases (GHGs) as a result of intensive human activities has contributed to global warming [1]. This warming occurs due to the presence of GHGs, which absorb the energy that would otherwise have escaped out into space, producing an increase in global temperature. Among the most important GHGs are $\mathrm{CO}_{2}, \mathrm{CH}_{4}, \mathrm{~N}_{2} \mathrm{O}, \mathrm{SF}_{6}$, hydrofluorocarbon (HFC), and perfluorocarbon (PFC), which were defined by the United Nations in the Kyoto Protocol. Of these gases, $\mathrm{CO}_{2}$ has been reported to be the main substance of anthropogenic origin that increases the greenhouse effect [2]. For this reason, several technologies have been developed as measures to mitigate $\mathrm{CO}_{2}$ emissions, either reducing anthropogenic $\mathrm{CO}_{2}$ emissions or capturing and sequestering atmospheric $\mathrm{CO}_{2}$ [3].

Within the technologies used for mitigation are the renewables energies, which are not completely free of emissions. Shrestha et al. [4] reported the average GHG emission rates estimated from several published studies on renewable energy processes. The emissions determined for the renewable energy sources in $\mathrm{g} \mathrm{CO}_{2 \mathrm{eq}} / \mathrm{kWh}$ are: 86 for biomass, 71 for solar (solar photovoltaic), 67 for geothermal, 31 for wind, and 25 for hydroelectric. For 
non-renewable energies (coal, oil, natural gas, and nuclear), average emissions are 1023, 780,606 , and $14 \mathrm{~g} \mathrm{CO}_{2 \mathrm{eq}} / \mathrm{kWh}$, respectively. Despite the increase in the use of renewable energies and the intensive search for better energy efficiency, fossil fuels are still preferred for energy generation due to their particular characteristics such as high energy density, easy use and storage, abundant supply, and, most attractive, their relatively low cost [5]. However, the combustion of fossil fuels releases large amounts of $\mathrm{CO}_{2}$ to the atmosphere, accounting for up to $65 \%$ of the total gases expelled [6]. This situation will continue to increase globally, so supporting technologies for renewable energies have to be employed, such as $\mathrm{CO}_{2}$ capture, either for long term storage or for reuse [7]. Within the technologies of carbon capture, use, and storage (CCUS), mineral carbonation (MC) is one of the most promising long term storage processes, since gaseous $\mathrm{CO}_{2}$ is fixed as a solid, minimizing the risk of subsequent leaks into the atmosphere [8,9].

$\mathrm{MC}$ occurs when $\mathrm{CO}_{2}$ reacts with oxides, hydroxides, or silicates of calcium $(\mathrm{Ca}$,), magnesium $(\mathrm{Mg})$, and iron (Fe) to produce geologically stable carbonate species and silica. The following chemical reaction summarizes a family of reactions:

$$
(\mathrm{Ca}, \mathrm{Mg}, \mathrm{Fe}) \mathrm{SiO}_{3(\mathrm{~s})}+\mathrm{CO}_{2(\mathrm{~g})} \rightarrow(\mathrm{Ca}, \mathrm{Mg}, \mathrm{Fe}) \mathrm{CO}_{3(\mathrm{~s})}+\mathrm{SiO}_{2(\mathrm{~s})}+\text { heat }
$$

Usually, MC is an exothermic and spontaneous reaction in which conversion to carbonate is thermodynamically favored [10]. For example, for both $\mathrm{Mg}_{2} \mathrm{SiO}_{4(\mathrm{~s})}$ and $\mathrm{CaSiO}_{3(\mathrm{~s})}$ the reactions release $90 \mathrm{~kJ} / \mathrm{mol}$ [5]. This process was proposed for the first time by Seifritz [11] to improve the natural silicate weathering process, which has occurred throughout the geological time scale.

The stability of the products of the above mineral carbonation reaction is explained by the carbon atom being at its lowest energy level in the carbonate, which provides a storage life of more than 100 thousand years [12]. This technology is also attractive because of the abundance in nature of this type of silicate, with the capacity to sequester all the $\mathrm{CO}_{2}$ emitted by the processes of fossil fuel combustion [13]. Mineral carbonation is nothing more than a process of natural wear that occurs on geological scales, and therefore the process is extremely slow. Several studies have been presented to accelerate this process, including direct carbonation of the ore with $\mathrm{CO}_{2}$ to indirect complex multi-stage processes $[10,12,14]$. The main interest of the studies in this field has been oriented to accelerate the mineral carbonation reaction speed in order to justify its industrial implementation. The simplest carbonation route in terms of process design and operation is the direct gas-solid route, although the reaction is very slow, even at high temperatures and pressures [15]. Figure 1 depicts the direct route compared with the indirect route. Indirect mineral carbonation is more favored through the indirect route since higher purity products are produced and the $\mathrm{Ca}$ and $\mathrm{Mg}$ conversion rate to carbonates is considerably higher [16].

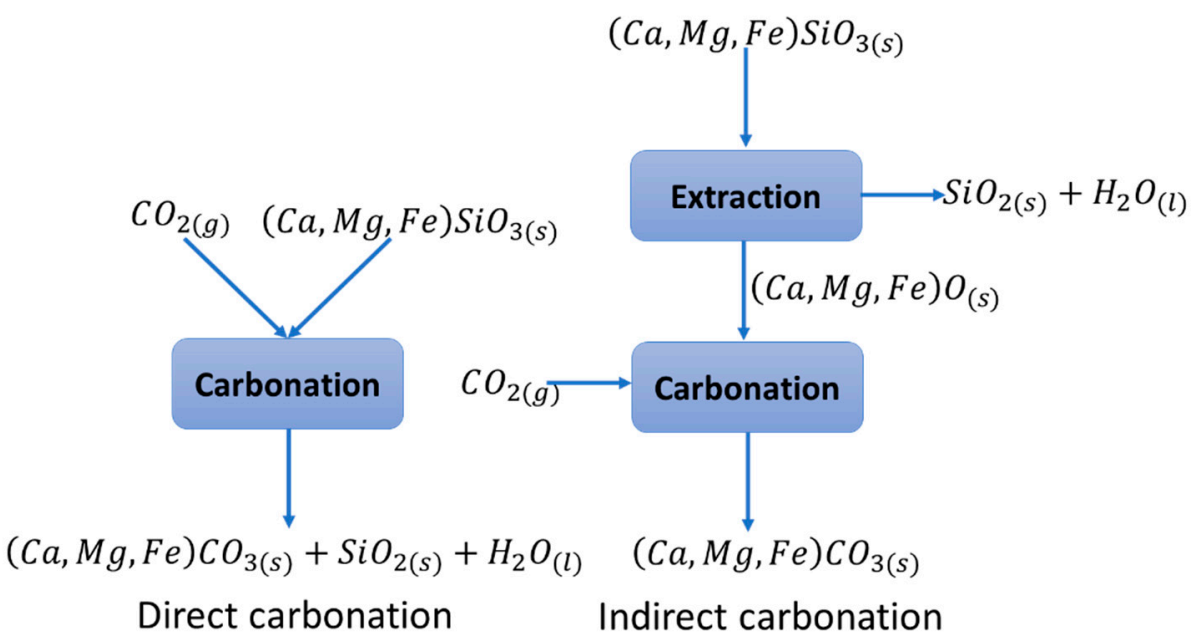

Figure 1. Direct and indirect carbonation gas-solid routes (adapted from Olajire [5]). 
Nowadays, the use of mining waste for mineral carbonation has received considerable interest due to the high potential for commercialization towards mitigating climate change. For example, recently, it has been determined that the tailing of the Dumont Nickel Project of RNC Minerals can capture about $16 \%$ of the $\mathrm{CO}_{2}$ annually emitted by their planned mining operation. In other words, the $15 \mathrm{Mt}$ of tailings produced each year may sequester 21,000 tonnes of $\mathrm{CO}_{2}$ per year by passive mineral carbonation [17]. Although $\mathrm{CO}_{2}$ capture is not yet economically competitive with other technologies, new laboratory, pilot, and field-scale studies should help to reduce its costs, energy use, and environmental effects [18]. There are several reviews on MC in the literature. Li et al. [19] reviewed the integration of MC in the mining industry, including the modified passive mineral carbonation techniques in tailing facilities. Additionally, they analyzed the techno-economic assessments on existing integrated MC technologies. They concluded that value-added by-products would play an essential role in the future commercialization of this technology. More recently, Hills et al. [20] reviewed MC in mineral wastes with a focus on the manufacture of carbonate-cemented products. Since it is not economically profitable to extract calcium and magnesium to only carry out MC [21], it is necessary to give it a profit to promote the deployment of this technology, being able to achieve this through the recovery of valuable metals from mine tailings. Recently, Araya et al. [22,23] investigated the techno-economic feasibility of critical raw materials recovery from copper mine tailings in northern Chile. They obtained positive net present values for the production of rare earth oxides and vanadium pentoxide $\left(\mathrm{V}_{2} \mathrm{O}_{5}\right)$. However, to analyze the potential of a tailings, it is necessary to evaluate different alternatives, including the extraction of valuable elements, elimination of toxic elements, new uses, among others. As in the initial phases of a study, not enough information is available to select technologies and carry out complete economic evaluations, the economic potential can be used to evaluate the economic performance of alternatives. For example, in the design of solids process the economic assessment between alternatives was performed at the initial step using the difference between the income from product sales and the cost of raw materials [24]. In another example, it was found that the income by sales can be an appropriate objective function to identify the optimal flotation circuit [25].

The main objective of this study was to analyze the potential of tailing deposits in Chile for the sequestration of $\mathrm{CO}_{2}$ by ex-situ mineral carbonation integrating the recovery of valuable metals. To reach this main objective, an inventory of mine tailing deposits and $\mathrm{CO}_{2}$ sources existing in Chile was constructed, and the most suitable sites for the installation of a future MC plant were identified. Additionally, the technical, economic and environmental feasibility of $\mathrm{CO}_{2}$ capture, separation, and transport from the source site to the MC plant was discussed.

\subsection{Mineral Carbonation}

Mafic and ultramafic rocks are the most suitable tailing material for MC due to their high content of $\mathrm{Ca}, \mathrm{Mg}$, and $\mathrm{Fe}$ with low-grade potassium $(\mathrm{K})$ and silica $\left(\mathrm{SiO}_{2}\right)$, and because they are available in large amounts around the world [26]. These rocks were formed by mineral groups such as olivine (fayalite or $\mathrm{Fe}_{2} \mathrm{SiO}_{4}$ and forsterite or $\mathrm{Mg}_{2} \mathrm{SiO}_{4}$ ), pyroxene (ferrosilite or $\mathrm{FeSiO}_{3}$, wollastonite or $\mathrm{CaSiO}_{3}$, and enstatite or $\mathrm{MgSiO}_{3}$ ), serpentine $\left(\mathrm{Mg}_{3} \mathrm{Si}_{2} \mathrm{O}_{5}(\mathrm{OH})_{4}\right)$, and Ca-plagioclase (anorthite or $\left.\mathrm{CaAl}_{2} \mathrm{Si}_{2} \mathrm{O}_{8}\right)$. However, other minerals such as biotite, anorthoclase, anorthite, orthoclase, and hornblende have shown the ability of $\mathrm{CO}_{2}$ capture $[27,28]$. These tailings can be treated using $\mathrm{MC}$ with either in-situ or ex-situ methods. The in-situ route refers to the process through which $\mathrm{CO}_{2}$ is directly injected into the bedrock, either as a supercritical fluid or as an aqueous solution, at high concentration and high temperature [29], reaching reaction rates of a million times higher than those occurring in nature [30]. The constant monitoring of fugitive emissions is necessary by this route, due to the possibility of leakage of carbon dioxide into the atmosphere, as well as harmful impurities [31]. The ex-situ route refers to sending $\mathrm{CO}_{2}$ and minerals to a chemical processing plant to induce MC. This involves a reduction in mineral size and the use of reagents (acid or base) in a multiple-stage, high-temperature, and high-pressure 
process [32]. In ex-situ MC, industrial solid wastes can be used, which are generally alkaline, inorganic, and rich in calcium and magnesium [10,15]. The main advantages of using industrial solid wastes for MC are that they are reacted faster than minerals to this process, tend to have relatively open structures and larger reactive surface areas. Besides, they are available at low cost, with less pretreatment and less intensive energy conditions in their treatment required, and they can encapsulate certain toxic elements into the solid matrix [10].

Some of the industrial wastes that can be treated through MC are steel slag, cement kiln dust, recycled concrete aggregate, municipal solid waste, incineration ash, air pollution control residue, coal fly ashes, wood ash, red mud, paper mill waste ash, and mine tailings (MT). In recent years, several works have focused on the use of different types of mine tailings for ex-situ MC. For instance, Pasquier et al. [33] proposed an innovative approach for the production of pure $\mathrm{MgCO}_{3}$ through the direct capture of $\mathrm{CO}_{2}$ from flue gases and sequestration using serpentine mine tailings at moderate temperature and pressure conditions. Meyer et al. [34] studied the feasibility of using pyroxene-rich mine tailings for $\mathrm{CO}_{2}$ storage through the two-stage $\mathrm{pH}$ swing method. In the experiment at $70{ }^{\circ} \mathrm{C}$ and a 2 $\mathrm{M} \mathrm{HCl}$ solution, the overall conversion of cations was $30 \%, 9 \%$, and $3 \%$ for $\mathrm{Ca}, \mathrm{Fe}$, and $\mathrm{Mg}$, respectively. Ben-Ghacham et al. [27] studied the use of anorthosite mine tailings and waste concrete in ex situ MC under low pressure and ambient temperature for the aqueous route. They reached removals of $34 \%$ and $66 \%$ from inlet $\mathrm{CO}_{2}$ using anorthosite mine tailing and waste concrete, respectively. Boschi et al. [35] studied the spontaneous $\mathrm{CO}_{2}$ sequestration through serpentine carbonation at ambient temperature in a copper mine located in Italy.

\subsection{Sources and Capture of Carbon Dioxide}

$\mathrm{CO}_{2}$ supply is another essential aspect to consider in MC processing of mine tailings. This gas is mainly produced from three sources: (1) industrial processes, (2) power production, and (3) fuel decarbonization. The largest $\mathrm{CO}_{2}$ sources are fossil fuels combustion power plants [36]. The advantage of sequestering $\mathrm{CO}_{2}$ emissions from power plants through $\mathrm{MC}$ has to do with the purity of the $\mathrm{CO}_{2}$ stream, due to the fact that impurities such as $\mathrm{NO}_{x}$ and $\mathrm{SO}_{x}$ do not have an impact on the carbonation process [37]. On the other hand, whether power plants are not located in the same site as the mine tailings, options for feedstock transport need to be evaluated [38]. Therefore, the evaluation of future MC projects should consider installing plants in sites with access to high $\mathrm{CO}_{2}$ supply. This evaluation plays an important role, since determining the most suitable site for the installation of a plant can minimize costs and harmful effects of the process on the environment [39]. For this purpose, mathematical and computational tools have been developed to support the evaluation of a finite number of decision alternatives, with the multi-criteria decision analysis methods (MCDA) being useful for selecting an optimum alternative, classifying alternatives, or ranking alternatives in a given preference order [40]. Specifically, the technique for order preference by similarity to ideal solution (TOPSIS) is a simple ranking method in its conception and application [41-44].

Within this context, the north of Chile appears to be a potential area for the installation of MC plants due to its extensive mining activity, mainly copper mining, located within the region of Antofagasta. This region produces more than half of the total amount of copper generated in Chile [45]. In 2017, 71\% of the refined copper in Chile was produced using concentration mill processes (from primarily sulfide copper minerals), whereas $29 \%$ was produced via leach, solvent extraction, and electrowinning processes (for secondary sulfide and oxidized copper minerals) [46]. This trend will increase in the future due to the reduction of oxidized minerals and the release of primarily sulfide minerals [47]. Thus, an increase is expected in the amount of copper mine tailings generated by flotation and concentration processes, which, in Chile, are electrically supplied by the National Electricity System (SEN), formed by two previous suppliers: the Interconnected Central System (SIC) and the Interconnected System of the Great Northern Region (SING). In 2017, 59\% of the electricity needs of the copper production industry was supplied by the SING system [46], 
whose electricity is generated from fossil fuel sources. One objective of this study was to assess the potential of tailings deposits in Chile for sequestration of $\mathrm{CO}_{2}$ by ex-situ MC, determining the most suitable site for installation of a MC plant, using the TOPSIS method.

\section{Methodology}

The methodology employed in this study consists of four main procedures: (1) construction of an inventory of the existing MT in Chile, (2) construction of an inventory of the thermoelectric power plants that provide energy to the mining plants, (3) application of the TOPSIS method, and (4) sensitivity analysis for site selection.

The purpose of constructing the MT inventory was to determine the quantity of $\mathrm{CO}_{2}$ that can be sequestered using those tailings as feedstock for MC, and identifying the other valuable species that can be to recovered from this tailing processing. The inventory of the thermoelectric power plants was constructed to quantify the $\mathrm{CO}_{2}$ that is available for sequestration. Next, TOPSIS was applied for the selection of the best site for installing a Mineral Carbonation plant. Finally, sensitivity analysis was performed to determine the influence of the different criteria for selecting the most suitable site for the installation of a MC plant.

\section{Collected Information}

The information collected and the number of tailing deposits and power plants are described and discussed in this section.

\subsection{Inventory of Tailing Deposits}

The data on tailing deposits in Chile were obtained from the National Service of Geology and Mining (SERNAGEOMIN) [48], which is the technical governmental entity responsible for the information of geological resources of the country. The data are permanently updated since the first version of the data was published in 2017. For the first version, the source information was obtained from samples taken during two years, corresponding to three sample locations: the surface of the bucket; the surface of the dam walls; and the downstream soil sediments. After 2017, the geochemical study included depth drilling of some tailings deposits. The estimation of the $\mathrm{CO}_{2}$ storage capacity of geological resources is the overriding factor to determine suitable $\mathrm{CO}_{2}$ storage sites [49]. Over 740 tailings deposits were registered in Chile as of 2019, which are distributed between the regions of Tarapacá in the north and Aysén in the south. The largest number of tailings is found in the regions of Coquimbo, Atacama, and Valparaiso (52.0\%, 21.5\%, and $10.5 \%$, respectively). The large number of tailings found in the Coquimbo region is due to the existence of many small mineral processing plants, which generate small tailing deposits. Regarding the operational status, $14.0 \%$ of the deposits are active, $23.4 \%$ are abandoned, and $62.6 \%$ are inactive. Active deposits are currently accumulating tailings; inactive deposits have reached the end of their useful life without executing legal closure but have a known responsible person; abandoned deposits have reached the end of their useful life, without executing legal closure and without a legal responsible person identified. In terms of volume, the 740 deposits have the capacity to contain a total volume of about $16,000 \mathrm{Mm}^{3}$. Figure 2 depicts the tailing deposits in Chile by region, including active, inactive, and abandoned tailing deposits, whereas Table 1 summarizes the current and approved volume of active tailing deposits.

Since 27 active tailings contribute $92.7 \%$ of the overall current tonnage of the 740 deposits, we used the data of these 27 active tailings deposits to analyze their chemical compositions to obtain an average value for further studies. The average chemical composition of these 27 tailing deposits active is presented in Table 2. In Table 2, REE means rare earth elements; minors are trace elements (below $100 \mathrm{ppm}$ ); majors are rock forming elements, expressed as oxides; $\mathrm{SD}$ is the standard deviation. REE includes $\mathrm{La}, \mathrm{Ce}, \mathrm{Pr}, \mathrm{Nd}$, $\mathrm{Sm}, \mathrm{Eu}, \mathrm{Gd}, \mathrm{Tb}, \mathrm{Dy}, \mathrm{Ho}, \mathrm{Er}, \mathrm{Tm}, \mathrm{Yb}, \mathrm{Lu}, \mathrm{Sc}$, and $\mathrm{Y}$; minors considers $\mathrm{Co}, \mathrm{Ni}, \mathrm{Cr}, \mathrm{Nb}, \mathrm{Cs}, \mathrm{Hf}$, $\mathrm{Ta}$, Th, $\mathrm{U}, \mathrm{Mo}, \mathrm{Sb}, \mathrm{Sn}, \mathrm{Ag}, \mathrm{Cd}, \mathrm{Bi}, \mathrm{W}, \mathrm{Au}$, and $\mathrm{Hg}$; and majors corresponds to $\mathrm{MnO}, \mathrm{P}_{2} \mathrm{O}_{5}$, 
and $\mathrm{SO}_{3}$. Furthermore, these values make it possible to assess the potential ecological risks of tailing deposits, through the concentrations of $\mathrm{As}, \mathrm{Cd}, \mathrm{Cr}, \mathrm{Cu}, \mathrm{Hg}, \mathrm{Pb}, \mathrm{Ni}, \mathrm{Zn}$, and using as a base the methodology proposed by Lam et al. [50].

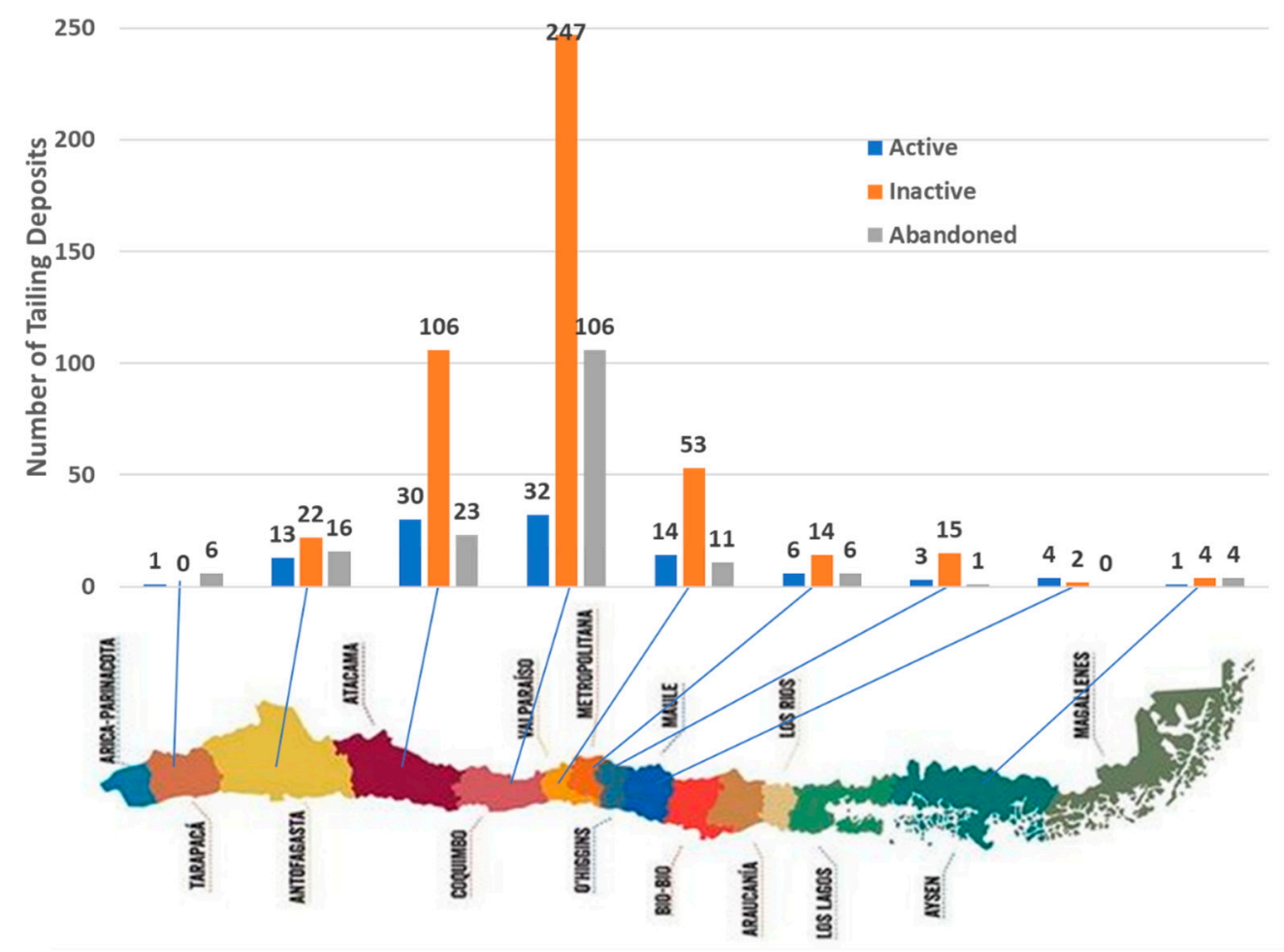

Figure 2. Number of tailing deposits in Chile 2019 by region.

Table 1. Current and approved volume of active tailing deposits. Vol., volume.

\begin{tabular}{ccccccc}
\hline Mining Size & Amount $\left.\mathbf{( N}^{\circ}\right)$ & Current Vol. $\mathbf{( \mathbf { M m } ^ { 3 } )}$ & $\mathbf{( \% )}$ & Approved Vol. $\mathbf{( \mathbf { M m } ^ { \mathbf { 3 } } )}$ & $\mathbf{( \% )}$ & Filling $\mathbf{( \% )}$ \\
\hline Small and medium & 77 & 69 & 1.0 & 189 & 1.2 & 36.51 \\
Large & 27 & 6639 & 99.0 & 14,939 & 98.8 & 44.44 \\
Total & 104 & 6708 & 100.0 & 15,128 & 100.0 & 44.34 \\
\hline
\end{tabular}

Table 2. Descriptive statistics of chemical composition and concentration (wt.\%) of tailing deposits active in Chile: values calculated based on data. REE: rare earth elements; SD: standard deviation.

\begin{tabular}{ccccccccccc}
\hline Descriptive Statistics & $\mathbf{C u}$ & $\mathbf{T i O}_{2}$ & $\mathbf{F e}_{2} \mathbf{O}_{3}$ & $\mathbf{C a O}$ & $\mathbf{M g O}$ & $\mathbf{N a}_{\mathbf{2}} \mathbf{O}$ & $\mathbf{K}_{\mathbf{2}} \mathbf{O}_{2}$ & $\mathbf{A l}_{\mathbf{2}} \mathbf{O}_{3}$ & $\mathbf{S i O}_{\mathbf{2}}$ & $\mathbf{M a j o r s}$ \\
\hline Mean & 0.098 & 0.565 & 9.570 & 3.326 & 3.159 & 2.645 & 3.424 & 14.497 & 56.949 & 5.332 \\
Median & 0.067 & 0.550 & 5.860 & 2.690 & 2.430 & 1.910 & 3.570 & 14.430 & 60.070 & 4.740 \\
SD & 0.087 & 0.189 & 8.170 & 2.348 & 1.973 & 2.733 & 1.339 & 3.034 & 9.728 & 3.666 \\
Kurtosis & 0.000 & 5.764 & -0.792 & 1.241 & 0.942 & 20.187 & -0.232 & -0.610 & -0.669 & 12.597 \\
Skewness & 0.000 & 1.474 & 0.870 & 0.977 & 1.132 & 3.887 & -0.313 & 0.087 & -0.467 & 3.102 \\
Min & 0.004 & 0.180 & 1.650 & 0.370 & 0.210 & 0.410 & 0.450 & 8.770 & 32.660 & 1.730 \\
Max & 0.367 & 1.400 & 27.530 & 11.020 & 9.260 & 18.350 & 6.010 & 21.450 & 73.570 & 23.870 \\
\hline Descriptive Statistics & $\mathbf{V}$ & $\mathbf{R b}$ & $\mathbf{Z n}$ & $\mathbf{S r}$ & $\mathbf{Z r}$ & $\mathbf{B a}$ & $\mathbf{P b}$ & $\mathbf{A s}$ & $\mathbf{R E E}$ & $\mathbf{M i n o r s}$ \\
\hline Mean & 0.013 & 0.010 & 0.027 & 0.025 & 0.027 & 0.058 & 0.021 & 0.009 & 0.016 & 0.036 \\
Median & 0.013 & 0.008 & 0.010 & 0.015 & 0.026 & 0.053 & 0.006 & 0.002 & 0.016 & 0.034 \\
SD & 0.004 & 0.006 & 0.051 & 0.022 & 0.014 & 0.030 & 0.051 & 0.022 & 0.006 & 0.012 \\
Kurtosis & 0.000 & 0.000 & 0.001 & 0.000 & 0.000 & 0.000 & 0.002 & 0.001 & 0.000 & 0.000 \\
Skewness & 0.000 & 0.000 & 0.000 & 0.000 & 0.000 & 0.000 & 0.000 & 0.000 & 0.000 & 0.000 \\
Min & 0.004 & 0.002 & 0.004 & 0.001 & 0.007 & 0.002 & 0.001 & 0.002 & 0.007 & 0.012 \\
Max & 0.027 & 0.033 & 0.262 & 0.076 & 0.061 & 0.125 & 0.259 & 0.106 & 0.037 & 0.082 \\
\hline
\end{tabular}


Elements of interest with high concentrations are observed in Table 2, such as $\mathrm{Cu}, \mathrm{TiO}_{2}$, $\mathrm{Fe}_{2} \mathrm{O}_{3}, \mathrm{CaO}, \mathrm{MgO}$, and REE. Elements such as $\mathrm{V}, \mathrm{Rb}, \mathrm{Zn}, \mathrm{Sr}, \mathrm{Zr}$, and $\mathrm{Ba}$ are in percentages above $0.01 \%$. Then, using these percentages as ore grade, that is, the ratio of contained valuable species per unit of ore (commonly expressed as a percentage, e.g., \%Cu) and knowing the total tonnage of the tailings ( Ton $_{\text {Total }}$ ), the tonnage of valuable species to be recovered $\left(\right.$ Ton $\left._{\mathrm{Val}}\right)$ was determined according to Equation (1).

$$
\operatorname{Ton}_{\text {Val }}=\text { Ton }_{\text {Total }} \times \text { ore grade }
$$

Then, considering the species with high concentration and those that cannot be treated by $\mathrm{MC}\left(\mathrm{Cu}, \mathrm{TiO}_{2}\right.$, and $\left.\mathrm{REE}\right)$, the income potential generated by their recovery can be calculated according to Equation (2) considering the market values of 6504, 9100 and $279,388 \mathrm{USD} / \mathrm{t}$ for $\mathrm{Cu}, \mathrm{TiO}_{2}$, and mean REE., respectively.

$$
\text { Income potential }=\left(\mathrm{Ton}_{\mathrm{Cu}} \times \mathrm{USD} / \mathrm{t}_{\mathrm{Cu}}\right)+\left(\mathrm{Ton}_{\mathrm{TiO} 2} \times \mathrm{USD} / \mathrm{t}_{\mathrm{TiO} 2}\right)+\left(\mathrm{Ton}_{\mathrm{REE}} \times \mathrm{USD} / \mathrm{t}_{\mathrm{REE}}\right)
$$

When considering the species treatable by $\mathrm{MC}$, the theoretical potential of sequestration can be estimated considering a maximum and minimum (Total $\mathrm{CO}_{2}(\min , \max )$ ). This is calculated using the maximum and minimum theoretical capacity of the sequestration of some minerals $\left(\mathrm{CO}_{2 \text { max.cap }}\right)$, which are given in $\mathrm{g}$ of $\mathrm{CO}_{2}$ that can be sequestered for each $100 \mathrm{~g}$ of mineral feed. Based on the methodology proposed by Vogeli et al. [51], and assuming the mineralogical compositions from copper mine tailings in northern Chile are obtained using the quantitative evaluation of minerals by scanning electron microscopy (QEMSCAN) in the studies presented by Lam et al. [52] and Medina et al. [53], chlorite is the mineral with the highest capacity, at $39.6 \mathrm{~g} \mathrm{CO}_{2} / 100 \mathrm{~g}$ chlorite, whereas muscovite has the lowest capacity, at $5.5 \mathrm{~g} \mathrm{CO}_{2} / 100 \mathrm{~g}$ muscovite. Table 3 lists more details. The minerals indicated in Table 3 were obtained from Chilean tailings analysis, available in the literature. The references where they were identified correspond to magnetite, chlorite, albite, and muscovite [52-57], biotite [52,54,56,57], orthoclase [52-54,56], albite [52-54,57], anorthite [53,55], titanite, hornblende, and montmorrillonite [52,57]. Additionally, amphibole-pyroxene was observed in Medina et al. [53] but was not considered in this study.

\begin{tabular}{|c|c|c|c|}
\hline Group & $\underset{(100 \mathrm{~g})}{\text { Mineral }}$ & Direct Mineral Carbonation Reaction & $\begin{array}{c}\mathrm{CO}_{2 \text { max.cap }} \\
\text { (g of } \mathrm{CO}_{2} / 100 \mathrm{~g} \text { Mineral) }\end{array}$ \\
\hline Oxides & Magnetite & $\mathrm{Fe}_{3} \mathrm{O}_{4}+\mathrm{CO}_{2}+\mathrm{H}_{2} \mathrm{O} \rightarrow \mathrm{FeCO}_{3}+2 \mathrm{FeOOH}$ & 19.0 \\
\hline \multirow[t]{4}{*}{ Phyllosilicates } & Biotite & $\mathrm{KMg}_{2} \mathrm{FeAlSi}_{3} \mathrm{O}_{10}(\mathrm{OH})_{2}+3 \mathrm{CO}_{2} \rightarrow 2 \mathrm{MgCO}_{3}+\mathrm{FeCO}_{3}+\mathrm{KAlSi}_{3} \mathrm{O}_{8}+\mathrm{H}_{2} \mathrm{O}$ & 29.4 \\
\hline & Chlorite & $\mathrm{Mg}_{5} \mathrm{Al}_{2} \mathrm{Si}_{3} \mathrm{O}_{10}(\mathrm{OH})_{8}+5 \mathrm{CO}_{2} \rightarrow 5 \mathrm{MgCO}_{3}+\mathrm{Al}_{2} \mathrm{O}_{3}+3 \mathrm{SiO}_{2}+4 \mathrm{H}_{2} \mathrm{O}$ & 39.6 \\
\hline & Montmorrillonite & $\mathrm{Na}_{0.33} \mathrm{Mg}_{2} \mathrm{Si}_{4} \mathrm{O}_{10}(\mathrm{OH})_{2} \mathrm{H}_{2} \mathrm{O}+2 \mathrm{CO}_{2} \rightarrow 2 \mathrm{MgCO}_{3}+0.33 \mathrm{NaO}_{3}+4 \mathrm{SiO}_{2}+2 \mathrm{H}_{2} \mathrm{O}$ & 23.1 \\
\hline & Muscovite & $2 \mathrm{KAl}_{2}\left(\mathrm{AlSi}_{3} \mathrm{O}_{10}\right)(\mathrm{OH})_{2}+\mathrm{CO}_{2} \rightarrow \mathrm{K}_{2} \mathrm{CO}_{3}+3 \mathrm{Al}_{2} \mathrm{O}_{3}+6 \mathrm{SiO}_{2}+2 \mathrm{H}_{2} \mathrm{O}$ & 5.5 \\
\hline \multirow[t]{3}{*}{ Tectosilicates } & Orthoclase & $2 \mathrm{KAlSi}_{3} \mathrm{O}_{8}+\mathrm{CO}_{2} \rightarrow \mathrm{K}_{2} \mathrm{CO}_{3}+\mathrm{Al}_{2} \mathrm{O}_{3}+6 \mathrm{SiO}_{2}$ & 7.9 \\
\hline & Albite & $2 \mathrm{NaAlSi}_{3} \mathrm{O}_{8}+\mathrm{CO}_{2} \rightarrow \mathrm{Na}_{2} \mathrm{CO}_{3}+\mathrm{Al}_{2} \mathrm{O}_{3}+6 \mathrm{SiO}_{2}$ & 8.4 \\
\hline & Anorthite & $\mathrm{CaAl}_{2} \mathrm{Si}_{2} \mathrm{O}_{8}+\mathrm{CO}_{2} \rightarrow \mathrm{CaCO}_{3}+\mathrm{Al}_{2} \mathrm{O}_{3}+2 \mathrm{SiO}_{2}$ & 15.8 \\
\hline \multirow[t]{2}{*}{ Other silicates } & Titanite & $\mathrm{CaTiSiO}_{5}+\mathrm{CO}_{2} \rightarrow \mathrm{CaCO}_{3}+\mathrm{TiO}_{2}+\mathrm{SiO}_{2}$ & 22.5 \\
\hline & Hornblende & $\mathrm{Ca}_{2} \mathrm{Mg}_{4} \mathrm{Al}\left(\mathrm{Si}_{7} \mathrm{Al}\right) \mathrm{O}_{22}(\mathrm{OH})_{2}+6 \mathrm{CO}_{2} \rightarrow 4 \mathrm{MgCO}_{3}+2 \mathrm{CaCO}_{3}+\mathrm{Al}_{2} \mathrm{O}_{3}+7 \mathrm{SiO}_{2}+\mathrm{H}_{2} \mathrm{O}$ & 32.4 \\
\hline
\end{tabular}

Table 3. Maximum theoretical mass of $\mathrm{CO}_{2}$ in ( $\mathrm{g}$ of $\mathrm{CO}_{2} / 100 \mathrm{~g}$ mineral) that can be sequestered by minerals.

The mineralogical compositions of the 27 active tailings were not available, so it was assumed that all the tonnage values obtained from Equation (1) for the species of $\mathrm{Na}, \mathrm{K}$, $\mathrm{Ca}, \mathrm{Mg}$, and Fe are present as the minerals presented in Table $3\left(\mathrm{Ton}_{(\mathrm{Na}, \mathrm{K}, \mathrm{Ca}, \mathrm{Mg}, \mathrm{Fe})}\right)$. Then, using Equation (3), the amount of $\mathrm{CO}_{2}$ that can be sequestered by the 27 active tailings for each of the species $\left(\mathrm{CO}_{2 \mathrm{SEQ}}\right)$ was determined.

$$
\mathrm{CO}_{2 \mathrm{SEQ}}=\mathrm{Ton}_{(\mathrm{Na}, \mathrm{K}, \mathrm{Ca}, \mathrm{Mg}, \mathrm{Fe})} \times \mathrm{CO}_{2 \mathrm{max} . \mathrm{cap}} / 100
$$


Whether the minimum and maximum values of $\mathrm{CO}_{2 \mathrm{SEQ}}$ for each of the $\mathrm{Na}, \mathrm{K}, \mathrm{Ca}, \mathrm{Mg}$, and Fe species are considered, the minimum and maximum amount of $\mathrm{CO}_{2}$ that can be sequestered can be determined, as shown in Equation (4).

$$
\text { Total } \mathrm{CO}_{2(\min )}=\left(\mathrm{CO}_{2 \mathrm{SEQ}} \text { by } \mathrm{Ca}\right)_{(\min )}+\left(\mathrm{CO}_{2 \mathrm{SEQ}} \text { by } \mathrm{Mg}\right)_{(\min )}+\left(\mathrm{CO}_{2 \mathrm{SEQ}} \text { by Fe }\right)_{(\min )}
$$

These 27 active tailings deposits are distributed between the Tarapacá and the O"Higgins regions (2000 km approx.). Considering this distance, a single MC plant to treat all the tailings would not be environmentally feasible due to the contamination produced by transporting only the tailings to the MC plant, which would considerably reduce the overall efficiency of the sequestration process, directly increasing the total cost of $\mathrm{CO}_{2}$ avoided (USD/t of $\mathrm{CO}_{2}$ ), which is already high. The idea was to integrate the MC plant, the tailings deposit, and the source from where the $\mathrm{CO}_{2}$ is obtained. The options for transporting $\mathrm{CO}_{2}$ were considered in the analysis, because the cost of $\mathrm{CO}_{2}$ transport, whether by trucks or pipes, increases with distance [51]. This aspect played an important role in the evaluation of the viability of the MC operation. The location of the 27 active tailing deposits is shown in Figure 3, which shows that the largest tonnage of active tailings, $37.1 \mathrm{wt} . \%$, is concentrated in the Antofagasta region, as well as the largest number of thermoelectric plants with installed capacity greater than $100 \mathrm{MW}$. Therefore, the Antofagasta region is considered the best location for the installation of a MC plant.

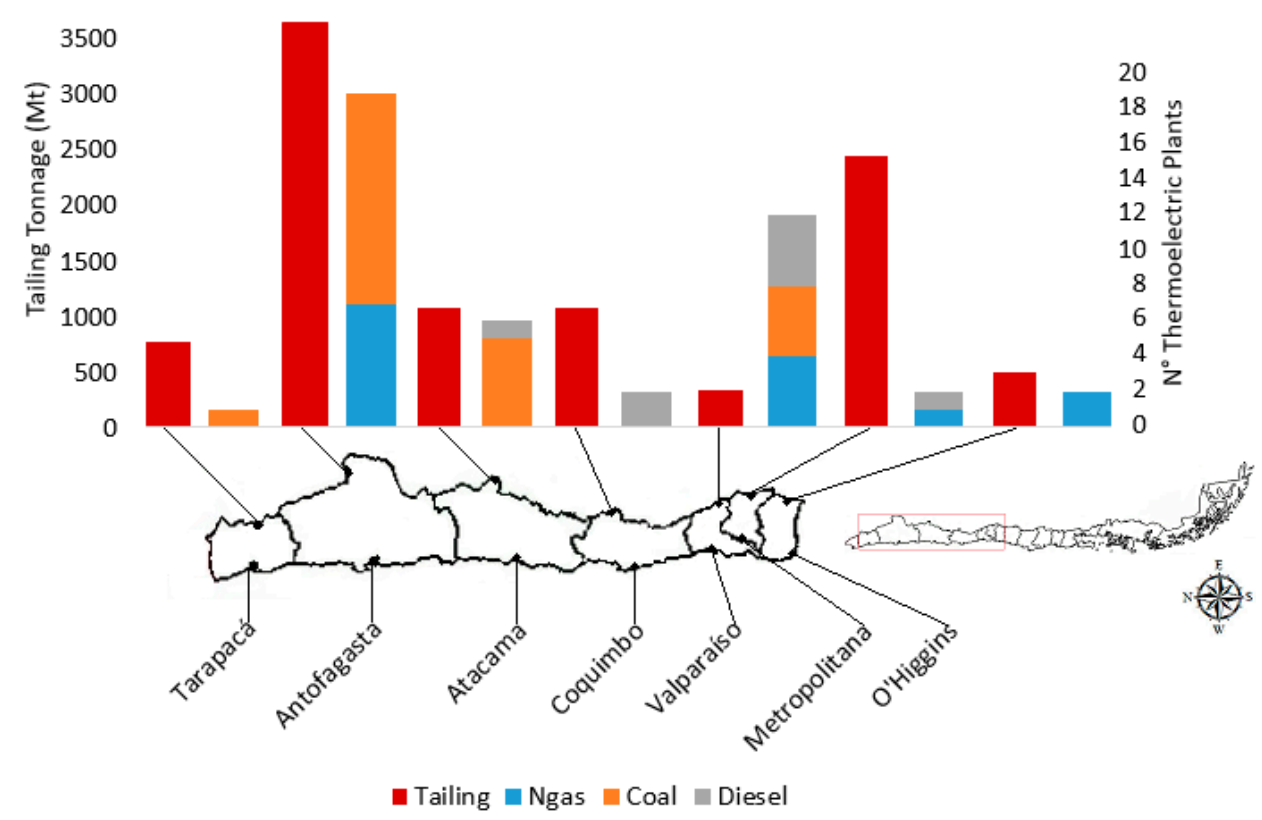

Figure 3. Distribution of active tailing deposits and thermoelectric plants in Chile by region.

\subsection{Inventory of Thermoelectric Power Plants}

The inventory of thermoelectric power plants was constructed for the Antofagasta region, and energy production data were obtained from the National Energy Commission (CNE) [58], which is the governmental entity responsible for the management of the technical standards with which companies involved in the production, generation, transport, and distribution energy must comply. The entity responsible for overseeing emission standards of thermoelectric plants is the Superintendence of the Environment, which through the legal standard Supreme Decree (DS, from the spanish Decreto Supremo) $\mathrm{N}^{\circ} 13 / 2011$, establishes the maximum emission limits for the exhaust gas flow $\left(\mathrm{Nm}^{3} / \mathrm{h}\right)$ and defines the source term as the electric generation unit that is operating or declared under construction. The emission limits depend on the type of fuel and whether the plant is already in operation or is new. Table 4 shows these values by compounds. However, the DS $N^{\circ} 13 / 2011$, does not establish a limit for other pollutants, harmful heavy metals, and 
$\mathrm{CO}_{2}$ emissions; for the latter it only establishes its continuous monitoring. Moreover, it does not clearly specify what will be the penalties that will be applied to those plants that do not comply with the stated emission limits [59].

Table 4. Emission limit values in Chile, according DS Nº13/2011 [59]. PM2.5: particulate matter 2.5.

\begin{tabular}{|c|c|c|c|c|c|}
\hline State of the Plant & Fuel & PM2.5 (mg/ $\left./ \mathrm{Nm}^{3}\right)$ & $\begin{array}{c}\mathrm{SO}_{2} \\
\left(\mathrm{mg} / \mathrm{Nm}^{3}\right)\end{array}$ & $\begin{array}{c}\mathrm{NO}_{\mathbf{x}} \\
\left(\mathrm{mg} / \mathrm{Nm}^{3}\right)\end{array}$ & $\underset{\left(\mathrm{mg} / \mathrm{Nm}^{3}\right)}{\mathrm{Hg}}$ \\
\hline \multirow{3}{*}{ In operation } & Solid & 50 & 400 & 500 & 0.1 \\
\hline & Liquid & 30 & 30 & 200 & - \\
\hline & Gas & - & - & 50 & - \\
\hline \multirow{3}{*}{ New } & Solid & 30 & 200 & 200 & 0.1 \\
\hline & Liquid & 30 & 10 & 120 & - \\
\hline & Gas & - & - & 50 & - \\
\hline
\end{tabular}

On the other hand, in the Antofagasta region, 19 thermoelectric plants have an installed capacity exceeding $100 \mathrm{MW}$, with a notable preference for the generation of energy by burning coal (Figure 3). In 12 plants, the installed capacity is about $2345 \mathrm{MW}$. The power generation efficiency (PGE) of each plant is determined according to Equation (5).

$$
\mathrm{PGE}=\left(\mathrm{ENE}_{2018} /(\mathrm{Cap} \times \mathrm{T})\right) \times 100
$$

In this equation, $\mathrm{T}$ is the number of operation hours when the plant is active throughout the year, Cap is the installed capacity of each power plants, measured in $\mathrm{MW}$, and $\left(\mathrm{ENE}_{2018}\right)$ is the total energy produced by each power plants during 2018 , measured in $\mathrm{MWh}$ /year. The value of T is determined as $8760 \mathrm{~h} /$ year, assuming that the thermoelectric plants operates during all year without interruptions. This is carried out to calculate the maximum amount of energy generated by each plant, as well as the maximum quantity of GHG emitted per year $\left(\mathrm{CO}_{2 \text { eq.max }}\right)$. This number was obtained by multiplying the energy generation by the respective emission factor (EMF), according to Equation (6). The emission factors for each fuel area were taken from Shrestha et al. [4]: $1023 \mathrm{CO}_{2 \mathrm{eq}} / \mathrm{kWh}$ for coal, $780 \mathrm{CO}_{2 \mathrm{eq}} / \mathrm{kWh}$ for oil, and $606 \mathrm{~g} \mathrm{CO}_{2 \mathrm{eq}} / \mathrm{kWh}$ for natural gas:

$$
\mathrm{CO}_{\text {2eq.MAX }}=\mathrm{Cap} \times \mathrm{T} \times \mathrm{EMF}
$$

To calculate the amount of $\mathrm{CO}_{2}$ emitted, instead of the amount of $\mathrm{CO}_{2 \text { eq. }}$ emitted, the composition of the exhaust gases of the thermoelectric plants that burn oil, coal, and natural gas obtained from Olajire [32], as well as the global warming potential (GWP) for each of the gases, is considered. The exhaust gases contain $54.91 \%, 59.94 \%$, and $80.99 \%$ $\mathrm{CO}_{2}$ for oil, coal, and natural gas, respectively. Then, the amount of $\mathrm{CO}_{2}$ generated by the thermoelectric plants in Antofagasta during 2018 was determined using Equation (7).

$$
\mathrm{CO}_{2.2018}=\mathrm{ENE}_{2018} \times \mathrm{EMF} \times \% \mathrm{CO}_{2} / 100
$$

\section{Selection of Sites for MC}

The TOPSIS method was used for the selection of the best site for installing a MC plant. Additionally, a sensitivity analysis was conducted to determine the influence of the different criteria on the selected site for the installation of the MC plant.

TOPSIS is a decision-making technique or MCDA, which, through a sequence of steps, is used to select the best alternative when comparing different criteria of a set of alternatives. Within these alternatives, none have exhibited superior performance for all criteria and an optimum alternative cannot be chosen [44]. The choice can be made by one or several experts, and, by using linguistic terms or numeric scale. However, its use and the selection of the criteria, the importance criteria weights, and the performance rating of each decision-maker must be chosen on a case-by-case basis. This technique was first proposed by Hwang and Yoon [60] on the basis that the best alternative must be located at 
the shortest distance of an ideal value and simultaneously at the greatest distance of an anti-ideal value. These distances were calculated to determine the closeness coefficient of each alternative, according to the following steps:

Step 1: Assignment of the set of alternatives (a), the criteria (i), and criteria weights $\left(w_{i}\right)$. The performance of $n$ alternatives a with respect to $m$ criteria $i$ are gathered in a decision matrix $X=\left(x_{i a}\right)$, where $\mathrm{i}=1, \ldots, \mathrm{m}$ and $\mathrm{a}=1, \ldots, \mathrm{n}$.

Step 2: The performance of the different criteria is normalized to enable comparison of the measurements with different units (e.g., km, USD, Mt). Here, several normalization methods can be used. In this work, the distributive normalization was employed, where the performance is divided by the square root of the sum of each squared element in a column:

$$
\mathrm{r}_{\mathrm{ia}}=\frac{\mathrm{x}_{\mathrm{ia}}}{\sqrt{\sum_{\mathrm{a}=1}^{\mathrm{n}} \mathrm{x}_{\mathrm{ia}}^{2}}} \text { where } \mathrm{i}=1, \ldots, \mathrm{m} \text {; and } \mathrm{a}=1, \ldots, \mathrm{n} \text {. }
$$

Step 3: The normalization values $\left(r_{i a}\right)$ are multiplied with their respective values of the criteria weights $\left(\mathrm{w}_{\mathrm{i}}\right)$ using Equation (9), and a weighted normalized decision matrix is generated.

$$
\mathrm{V}_{\mathrm{ia}}=\mathrm{w}_{\mathrm{i}} \times \mathrm{r}_{\mathrm{ia}}
$$

Step 4: The values of the weighted normalized decision matrix $\left(\mathrm{V}_{\mathrm{ia}}\right)$ are each compared with the ideal value $\left(\mathrm{V}_{\mathrm{i}}^{+}\right)$and with the anti-ideal value $\left(\mathrm{V}_{\mathrm{i}}^{-}\right)$of their respective criteria. $\mathrm{V}_{\mathrm{i}}^{+}$ and $\mathrm{V}_{\mathrm{i}}^{-}$are obtained, when collecting the best and worst performance on each criterion of the normalized decision matrix, according to Equations (10) and (11), respectively.

$$
\begin{aligned}
& \mathrm{A}^{+}=\left(\mathrm{V}_{1}^{+}, \ldots, \mathrm{V}_{\mathrm{m}}^{+}\right) \\
& \mathrm{A}^{-}=\left(\mathrm{V}_{1}^{-}, \ldots, \mathrm{V}_{\mathrm{m}}^{-}\right)
\end{aligned}
$$

where $\mathrm{V}_{\mathrm{i}}^{+}=\max _{\mathrm{a}}\left(\mathrm{V}_{\mathrm{ia}}\right)$ if criterion $\mathrm{i}$ is to be maximized and $\mathrm{V}_{\mathrm{i}}^{-}=\min _{\mathrm{a}}\left(\mathrm{V}_{\mathrm{ia}}\right)$ if criterion $\mathrm{i}$ is to be minimized.

Step 5: Calculate the distance between $V_{i a}$ and $V_{i}^{+}$and between $V_{i a}$ and $V_{i}^{-}$using Equations (12) and (13), respectively. We used a Euclidean distance, but another metric can be applied.

$$
\begin{aligned}
& \mathrm{d}_{\mathrm{a}}^{+}=\sqrt{\sum_{\mathrm{i}}\left(\mathrm{V}_{\mathrm{i}}^{+}-\mathrm{V}_{\mathrm{ia}}\right)^{2}} \\
& \mathrm{~d}_{\mathrm{a}}^{-}=\sqrt{\sum_{\mathrm{i}}\left(\mathrm{V}_{\mathrm{i}}^{-}-\mathrm{V}_{\mathrm{ia}}\right)^{2}}
\end{aligned}
$$

Step 6: The closeness coefficient $\left(\mathrm{CC}_{\mathrm{a}}\right)$ is determined for each of the alternatives using Equation (14). $\mathrm{CC}_{\mathrm{a}}$ varies between 0 and 1, where the best results are closer to 1 , and the worst results are closer to 0 .

$$
\mathrm{CC}_{\mathrm{a}}=\frac{\mathrm{d}_{\mathrm{a}}^{-}}{\mathrm{d}_{\mathrm{a}}^{+}+\mathrm{d}_{\mathrm{a}}^{-}}
$$

Step 7: The alternatives are ranked according to the $\mathrm{CC}_{\mathrm{a}}$ in decreasing order. The alternative with the highest score is selected as the most suitable site for the installation of a MC plant.

Finally, the sensitivity analysis was performed to determine the sensitivity of the general decision to small changes in the criteria weights assigned during TOPSIS application. This was achieved by slightly varying the values of weights of each criterion and then observing its effect on the general decision.

\section{Results and Discussion}

Figure 4 summarizes the amounts of valuable species that could be recovered from the largest tailing deposits in Chile, considering only the species that occur in larger quantities. Recovering all the species would not be feasible due to their low concentration. 


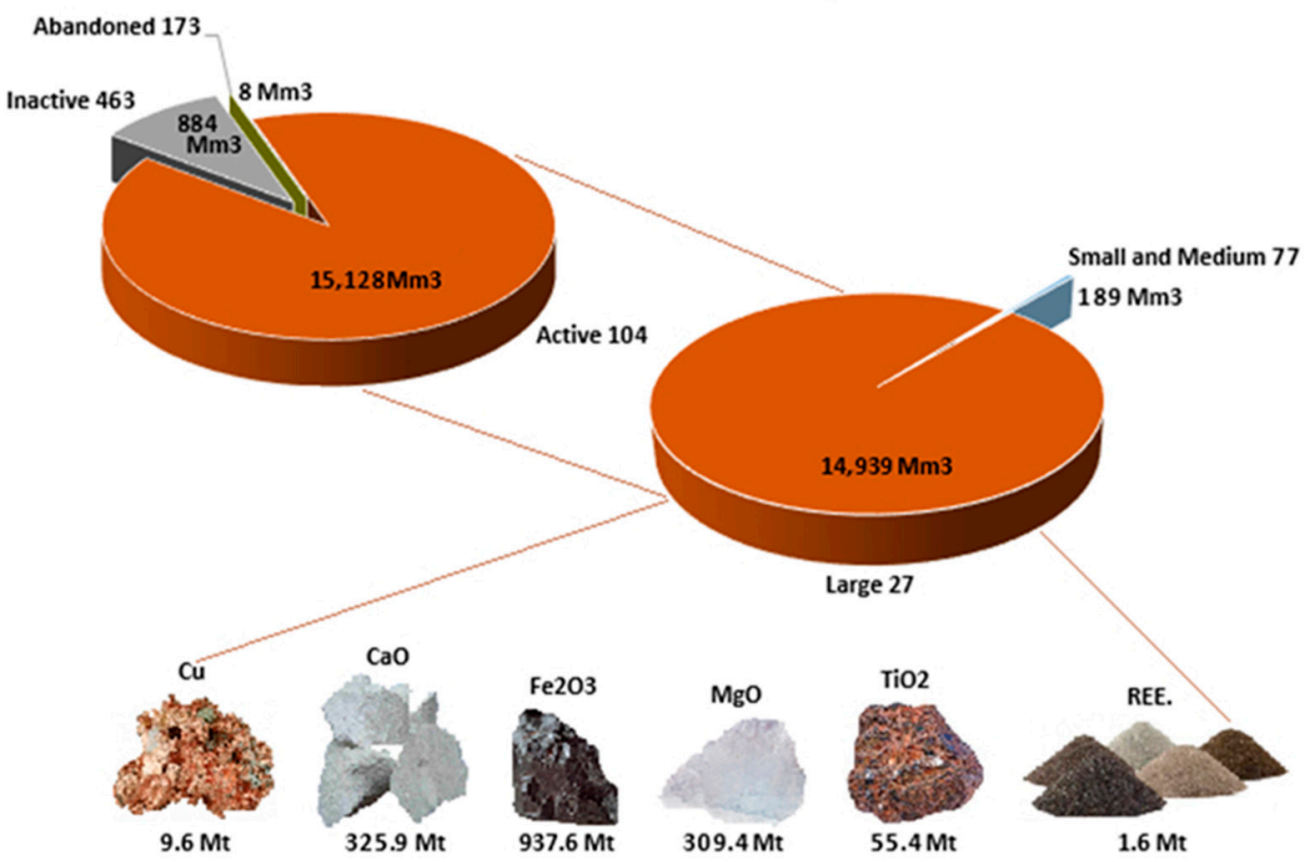

Figure 4. Valuable species tonnage that can be recovered from the largest tailing deposits in Chile.

The results indicated that 325.9 Mt of $\mathrm{Ca}$, 937.6 Mt of Fe, and 309.4 Mt of Mg exists, which can be used as feedstock for MC. Additionally, there are $9.6 \mathrm{Mt}$ of $\mathrm{Cu}, 55.4 \mathrm{Mt}$ of $\mathrm{TiO}_{2}$, and $1.6 \mathrm{Mt}$ of REE, contained in 27 of the total 740 deposits. On the other hand, Vogeli et al. [51] determined that the tailings rich in $\mathrm{Ca}$ and $\mathrm{Mg}$ produced by the main platinum mining industries in South Africa (Anglo American, Implats, Northam, and Lonmin) generated about 77.51 Mt/year of tailings between June 2009 and June 2010, which had the potential to theoretically sequester a total of about $13.94 \mathrm{Mt}$ of $\mathrm{CO}_{2} /$ year.

Chile generated around $318 \mathrm{Mt}$ of tailings in 2012, about $511 \mathrm{Mt}$ in 2016, and, by 2020, is expected to generate around $600 \mathrm{Mt}$ [61]. Of the 27 active tailings deposits, 37.1\% (wt.\%) of the total tonnage are located in the Antofagasta region in six large-scale active deposits. The deposit of Laguna Seca has the largest sequestration potential of $44.09 \mathrm{Mt}$ of $\mathrm{CO}_{2}$ due to its large tonnage, whereas the Esperanza deposit can sequester the greatest amount of $\mathrm{CO}_{2}$ per ton of tailings ( $0.044 \mathrm{t}$ of $\mathrm{CO}_{2} / \mathrm{t}$ of tailings). The Mantos Blancos deposit can generate the highest income potential per ton of tailings (124.35 USD/t of tailing). The El Peñón deposit has the lowest sequestration potential with $0.46 \mathrm{Mt}$ of $\mathrm{CO}_{2}$. Table 5 provides details of these results.

Five of the six deposits identified in Table 5 generate tailings from copper extraction, whereas El Peñón generates tailings from gold extraction. Additionally, the Mantos Blancos and Sierra Gorda deposits have high concentrations of REE (240 and $220 \mathrm{ppm}$, respectively), whereas the concentration in the rest of the world varies between 0.5 and $50 \mathrm{ppm}$. REE prices range between 5.5 to $1258 \mathrm{USD} / \mathrm{kg}$ for $\mathrm{CeO}_{2}$ and $\mathrm{Lu}_{2} \mathrm{O}_{3}$, respectively. Esperanza, Laguna Seca, and Mantos Blancos deposits have titanium oxide grades over 5000 ppm, whereas Talabre deposit has a copper grade over $2000 \mathrm{ppm}$. In addition, Lam et al. [50] performed a study using the same data from the National Service of Geology and Mining [48], and they determined that none of these six tailings deposits in Antofagasta are located at less than $2 \mathrm{~km}$ from a water body and at less than $2 \mathrm{~km}$ from a populated area, so regarding their location, these would not pose a potential environmental risk. However, regarding their heavy metal contamination it is possible to assess the potential ecological risks, so the six tailings were evaluated for $\mathrm{As}, \mathrm{Cd}, \mathrm{Hg}, \mathrm{Pb}, \mathrm{Cu}, \mathrm{Ni}, \mathrm{Zn}, \mathrm{Cr}$. Table 6 provides these results, and details of their determination can be found in the Supplementary Materials. Metal such as $\mathrm{Ni}, \mathrm{Zn}, \mathrm{Cu}$ and $\mathrm{Cr}$, do not represent an environmental risk, unlike $\mathrm{Pb}, \mathrm{Hg}$, $\mathrm{Cd}$, and As, all of them are highly toxic and the last three are carcinogens. The Esperanza 
deposit has the lowest risk index (RI), because none of its heavy metals are above the high level, followed by the Sierra Gorda deposit with one heavy metal at a very high level, the rest of the deposits have the RI at an extremely high level. El Peñon deposit has the highest RI, with this value far above the rest and with four heavy metals at extremely high levels, so this deposit for the authorities should represent a priority in its management.

Table 5. Potential of mass of $\mathrm{CO}_{2}$ to be sequester and mean sequestration efficiency (MSE) with tailing deposits of the Antofagasta region.

\begin{tabular}{|c|c|c|c|c|c|c|c|c|}
\hline & & Total CC & $\mathrm{O}_{2}(\mathrm{Mt})$ & MSE & & $\%$ & & Income Potential \\
\hline Tailing Deposit & $\begin{array}{l}\text { Current } \\
\text { Ton (Mt) }\end{array}$ & $\mathrm{CO}_{2 \min }$ & $\mathrm{CO}_{2 \max }$ & $\begin{array}{c}\left(\mathrm{t} \text { of } \mathrm{CO}_{2} /\right. \\
t \text { of Tailings) }\end{array}$ & $\mathrm{Cu}$ & $\mathrm{TiO}_{2}$ & REE & $\begin{array}{c}\text { (USD/ } \\
\text { t of Tailings) }\end{array}$ \\
\hline Mantos Blancos & 131 & 3.22 & 4.59 & 0.030 & 0.193 & 0.500 & 0.024 & 124.35 \\
\hline Esperanza & 240 & 8.41 & 12.62 & 0.044 & 0.040 & 0.590 & 0.015 & 97.24 \\
\hline Sierra Gorda & 143 & 3.25 & 4.86 & 0.028 & 0.052 & 0.490 & 0.022 & 109.18 \\
\hline Talabre & 1793 & 21.85 & 31.96 & 0.015 & 0.230 & 0.180 & 0.011 & 63.08 \\
\hline Laguna Seca & 1302 & 28.95 & 44.09 & 0.028 & 0.103 & 0.525 & 0.016 & 99.64 \\
\hline El Peñon & 21 & 0.31 & 0.46 & 0.019 & 0.048 & 0.280 & 0.017 & 75.71 \\
\hline Total & 3630 & 66.01 & 98.57 & & & & & \\
\hline
\end{tabular}

Table 6. Average heavy metal concentration values and potential ecological risk index for tailing deposits of the Antofagasta region (see last column for color definition).

\begin{tabular}{|c|c|c|c|c|c|c|c|c|c|c|}
\hline \multirow[b]{2}{*}{ Tailing Deposit } & \multicolumn{8}{|c|}{$\begin{array}{l}\text { Ecological Risk Factor }\left(E_{r}\right) \\
\text { (Dimensionless) }\end{array}$} & \multirow{2}{*}{$\begin{array}{c}\text { Potential Ecological } \\
\text { Risk Index }\left(\sum \mathrm{E}_{\mathrm{r}}\right)\end{array}$} & \multirow[t]{2}{*}{$\begin{array}{c}\text { Contamination } \\
\text { Level }\end{array}$} \\
\hline & As & $\mathrm{Cd}$ & $\mathrm{Hg}$ & $\mathrm{Pb}$ & $\mathrm{Cu}$ & $\mathrm{Ni}$ & Zn & $\mathrm{Cr}$ & & \\
\hline Mantos Blancos & 40 & 223 & 5 & 89 & 72 & 10 & 1 & 5 & 444 & Low \\
\hline Esperanza & 40 & 33 & 73 & 50 & 15 & 5 & 2 & 3 & 220 & Middle \\
\hline Sierra Gorda & 40 & 140 & 11 & 56 & 19 & 5 & 1 & 3 & 276 & High \\
\hline Talabre & 1562 & 65 & 143 & 470 & 85 & 9 & 2 & 2 & 2339 & Very high \\
\hline Laguna Seca & 40 & 67 & 355 & 65 & 38 & 2 & 5 & 4 & 575 & Extremely high \\
\hline El Peñon & 1953 & 327 & 596 & 1615 & 18 & 9 & 25 & 2 & 4545 & \\
\hline
\end{tabular}

Regarding thermoelectric plants, Table 7 lists the existing plants with an installed capacity exceeding $100 \mathrm{MW}$ (19 plants), of which the most are located in the district of Mejillones, followed by Tocopilla and then Taltal. The higher use of coal plants than natural gas plants was observed (PGE\%), mainly due to the discontinuous supply of natural gas from Argentina, which is the fuel used by some of these plants.

However, the natural gas shipment of gas from Argentina to Chile has been restored, which provides Chile with new opportunities to decarbonize its energy matrix, as well as to increase the flexibility of its electrical system. The main results show that 19 plants together generated a total of $15,954 \mathrm{GWh}$ in 2018, producing a total of $9.37 \mathrm{Mt}$ of $\mathrm{CO}_{2}$ that is available to be sequestered, with a maximum potential of $21.89 \mathrm{Mt}$ of $\mathrm{CO}_{2 \mathrm{eq}}$ per year. Finally, five large-scale active deposits have the potential to sequester about $66 \mathrm{Mt}$ of $\mathrm{CO}_{2}$, considering the least favorable case (total $\mathrm{CO}_{2 \mathrm{~min}}$ ). Only in the processing of the Talabre or Laguna Seca deposits using MC could practically all the $\mathrm{CO}_{2}$ generated in 2018 by thermoelectric plants could be sequestered. This presents a considerable challenge, considering that the project in operation with the largest $\mathrm{CO}_{2}$ capture capacity in the world is Century Plant, capturing 8.4 Mt of $\mathrm{CO}_{2}$ per year, followed by Shute Creek Gas Processing Plant, capturing 7.0 Mt of $\mathrm{CO}_{2}$ per year, both located in the USA [62]. 
Table 7. Distribution, capacity, efficiency (PGE), and $\mathrm{CO}_{2}$ to be sequestered of thermoelectric plants greater than $100 \mathrm{MW}$ in Antofagasta region. NGas: natural gas; ANG1, ANG2: Angamos thermoelectric power plants; CC KELAR: Kelar thermoelectric power plant; $\mathrm{CCH} 1, \mathrm{CCH}$ : Cochrane thermoelectric power plants; $\mathrm{CC} 1, \mathrm{CC} 2$ : Atacama thermoelectric power plants; CTA: Andina thermoelectric power plant; CTH: Hornitos thermoelectric power plant; CTM1-3: Mejillones thermoelectric power plants; NTO1, NTO2: Norgener thermoelectric power plants; TAL1, TAL2: Taltal thermoelectric power plants; U14-16: Tocopilla thermoelectric power plants.

\begin{tabular}{|c|c|c|c|c|c|c|c|}
\hline Facility & Location & Source & $\begin{array}{l}\text { Capacity } \\
\text { (MW) }\end{array}$ & $\begin{array}{l}\text { PGE } \\
(\%)\end{array}$ & $\begin{array}{c}\text { ENE }_{2018} \\
\left(G W h / \text { year }_{2018}\right)\end{array}$ & $\begin{array}{c}\mathrm{CO}_{\text {2eq.MAX }} \\
\text { (Mt/year) }\end{array}$ & $\begin{array}{c}\mathrm{CO}_{2.2018} \\
\left(\mathrm{Mt} / \text { year }_{2018}\right)\end{array}$ \\
\hline $\mathrm{NTO} 1+\mathrm{NTO} 2$ & Tocopilla & Coal & 276.39 & 75.6 & 1831 & 1.48 & 1.12 \\
\hline U14-U16 & Tocopilla & Coal/NGas & 631.10 & 36.1 & 1997 & 3.00 & 1.10 \\
\hline CTM1-CTM3 & Mejillones & Coal/NGas & 583.29 & 23.4 & 1197 & 2.87 & 0.69 \\
\hline $\mathrm{CTH}$ & Mejillones & Coal & 177.54 & 60.8 & 945 & 0.95 & 0.58 \\
\hline ANG1 + ANG2 & Mejillones & Coal & 558.20 & 75.3 & 3681 & 3.00 & 2.26 \\
\hline $\mathrm{CCH} 1+\mathrm{CCH} 2$ & Mejillones & Coal & 549.72 & 68.0 & 3277 & 2.95 & 2.01 \\
\hline CTA & Mejillones & Coal & 177.00 & 65.4 & 1015 & 0.95 & 0.62 \\
\hline CC KELAR & Mejillones & NGas & 532.46 & 39.2 & 1829 & 2.29 & 0.90 \\
\hline $\mathrm{CC} 1+\mathrm{CC} 2$ & Mejillones & NGas & 780.60 & 1.9 & 127 & 3.36 & 0.06 \\
\hline \multirow[t]{2}{*}{ TAL1 + TAL2 } & Taltal & NGas & 240.15 & 2.6 & 55 & 1.03 & 0.03 \\
\hline & & & & Total & 15,954 & 21.89 & 9.37 \\
\hline
\end{tabular}

To illustrate the challenge of integrating MC plants, the tailing deposit locations, and the thermoelectric plants, Figure 5, constructed using the software Google Earth, presents the geographical location of the 19 thermoelectric plants and five copper tailing deposits. In the Antofagasta region, the thermoelectric plants are located on the coast (red markers), 12 of which are located in a small area of the Mejillones Peninsula, whereas the tailing deposits are located in the coastal mountain (green markers). For tailing deposits, the distance to the nearest $\mathrm{CO}_{2}$ source and the altitude were defined based on topography data from Google Earth [48]. The location of the MC plant should be closest to one of the tailing deposits since transporting the $\mathrm{CO}_{2}$ to the mine site is preferable compared to transporting large amounts of ore to the $\mathrm{CO}_{2}$ source site [38]. $\mathrm{CO}_{2}$ transportation from the thermoelectric plants on the coast to the tailing deposits, where the MC plant should be constructed, could be performed by pipelines through a $\mathrm{CO}_{2}$ distribution network. $\mathrm{CO}_{2}$ pipelines could be installed close to water pipelines, which exist in this area and that send desalinated water from the reverse osmosis plants on the coast to the mining sites, in order to prorate the right of way cost and favor legal and engineering advantages. Pipeline transport is considered the best option when it comes to transporting $\mathrm{CO}_{2}$ over long distances and in large volumes [63]. Particularly, in the U.S. over $6000 \mathrm{~km}$ of pipelines exist, intended for the $\mathrm{CO}_{2}$ supply for enhanced oil recovery projects [64]. Pipeline transport is a mature technology, which is applied on a wide scale across the world. However, the cost of transporting $\mathrm{CO}_{2}$ can play an important role considering the distances and the difference in level between the thermoelectric plants and the tailings deposits. The risks of this activity for the environment and population largely depend on local conditions, population density, and other risky activities that are carried out close to the pipelines. However, the mitigating of these risks is part of the existing knowledge [64]. Regarding $\mathrm{CO}_{2}$ capture, aqueous monoethanolamine (MEA) is the most common absorbent used to $\mathrm{CO}_{2}$ separation, due to its good rates of $\mathrm{CO}_{2}$ mass transfer, is suitable for low $\mathrm{CO}_{2}$ partial pressure conditions, is biodegradable and low cost [49]. Karimi et al. [65] determined the cost of $\mathrm{CO}_{2}$ avoided is about $55.7 \mathrm{USD} / \mathrm{t}$ of $\mathrm{CO}_{2}$ for a $150 \mathrm{MW}$ post-combustion power plant using MEA. On the other hand, Valderrama et al. [66] indicated that ionic liquids represent an attractive form of capturing and transporting $\mathrm{CO}_{2}$ for its sequestration in mine tailings. Additionally, Mena and Guirado [67] determined that the use of copper electrodes and ionic liquids to capture and transform $\mathrm{CO}_{2}$ into value-added products is a suitable and greener alternative compared to other CCUS strategies. Regarding $\mathrm{CO}_{2}$ sequestration, the use of mine tailings for MC eliminates the cost of mining, crushing, and 
milling associated with primary mining, considerably reducing energy consumption and thus $\mathrm{CO}_{2}$ emissions [5]. Moreover, is possible to reduce the main cost of the ex-situ MC, when sharing the comminution cost with the flow sheet of valuable metal recovery. The whole process may be profitable through the valuable metal recovery, as well as carbon taxes. For example, the copper Chilean mining generates 3.0 tons of $\mathrm{CO}_{2 \text { eq }}$ per ton of copper produced, a value above the world average which is 2.6 [68], and also has a production cost of $217 \mathrm{cUSD} / \mathrm{lb}$ of $\mathrm{Cu}$. So considering a market value of $296 \mathrm{cUSD} / \mathrm{lb}$ of $\mathrm{Cu}$, a cost for $\mathrm{CO}_{2}$ transport and storage of $228 \mathrm{USD} / \mathrm{t}$ of $\mathrm{CO}_{2}$ captured [69], and $50 \%$ extra in the cost of production, due to the difficulty of extracting copper from tailings, the value of $\mathrm{CO}_{2}$ taxes to profitable in the whole process should be about USD 12 and 24 per ton of $\mathrm{CO}_{2 \text { eq }}$ for the Esperanza and Sierra Gorda deposits, respectively. Meanwhile, in China, Denmark, and the Netherlands, the value of $\mathrm{CO}_{2}$ taxes is about USD 1.43, 14.3, and 25 per ton of $\mathrm{CO}_{2 \text { eq, }}$, respectively [70]. These values are a preliminary economic assessment that allows an analysis of the potential viability of a tailing project. After this assessment, a pre-feasibility study is necessary. This pre-feasibility study must look at the mineralogy, engineering, and economic factors, with a higher detail and precision level. The conclusions can change because there are uncertainties in the current analysis. For example, more negative conclusions will result if the assessment includes recoveries below $100 \%$ for copper and higher costs. On the contrary, a more optimistic position results will be found if a higher copper price is considered (the current price is over $400 \mathrm{cUSD} / \mathrm{lb} \mathrm{Cu}$ with which positive revenues are obtained), recovery of $\mathrm{REE}$ or $\mathrm{TiO}_{2}$ is considered (positive revenues are obtained in this case), and reduction of the costs. If the milling costs are subtracted from the considered costs, the $\mathrm{CO}_{2}$ taxes go down to USD 7 and 13 per ton of $\mathrm{CO}_{2 \text { eq }}$ for the Esperanza and Sierra Gorda deposits, respectively. Additionally, the copper industry faces a paradox in that copper is key to the overall global low carbon renewable energy challenge, but the supply chain delivering copper still has a high carbon footprint. Then, several copper producers seek to reduce the levels of $\mathrm{CO}_{2}$ generation in order to differentiate their product from the conventional one to add value to their products. In addition, there is the possibility of obtaining commercial by-products as material for construction, road material, additives for cement, among others, which could reduce the total cost of $\mathrm{CO}_{2}$ sequestration and reduce the amount of material that ends up in the tailing deposits [10,71]. However, since it is a mining operation, thes potential contamination of soil, water, and air in surrounding areas exists, whereby the implementation of this technology must have a suitable protocol of management and control environment. All these topics are beyond the scope of this investigation, which is focused on determining the most suitable site for the installation of the MC plant.

Regarding the TOPSIS method application, the following criteria were considered: (1) the average total amount of $\mathrm{CO}_{2}$ that is able to be sequestered by the tailing, measured in $\mathrm{Mt}$ of $\mathrm{CO}_{2}(\mathrm{C} 1)$; (2) income potential generated by the tailing in its processing, considering the sale of copper, titanium oxide, and REE, measured in USD/t of tailing (C2); (3) sequestration efficiency of the tailing, measured in $\mathrm{t}$ of $\mathrm{CO}_{2} / \mathrm{t}$ of tailing (C3); (4) copper grade, measured in \% (C4); (5) titanium oxide grade, measured in \% (C5); (6) rare earth grade, measured in \% (C6); (7) altitude at which the tailings deposit is located, measured in meters above

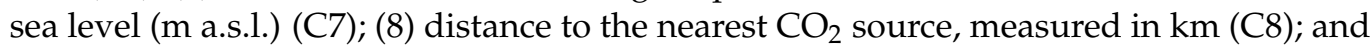
(9) potential ecological risk index, which is dimensionless (C9). Criteria C1 to C6 and C9 need to be maximized, whereas $C 7$ and $C 8$ need to be minimized. The $C C_{a}$ obtained using TOPSIS were 0.46 for the Mantos Blanco (MB) deposit, 0.34 for ES, 0.31 for SG, 0.56 for Talabre (TA), and 0.45 for the Laguna Seca (LS) deposit. Details in the TOPSIS method results can be found in the Supplementary Materials. In the first instance (test T1), the highest value was obtained by the TA deposit. However, changes that may occur when the criteria weights change should also be analyzed for making the final decision. 


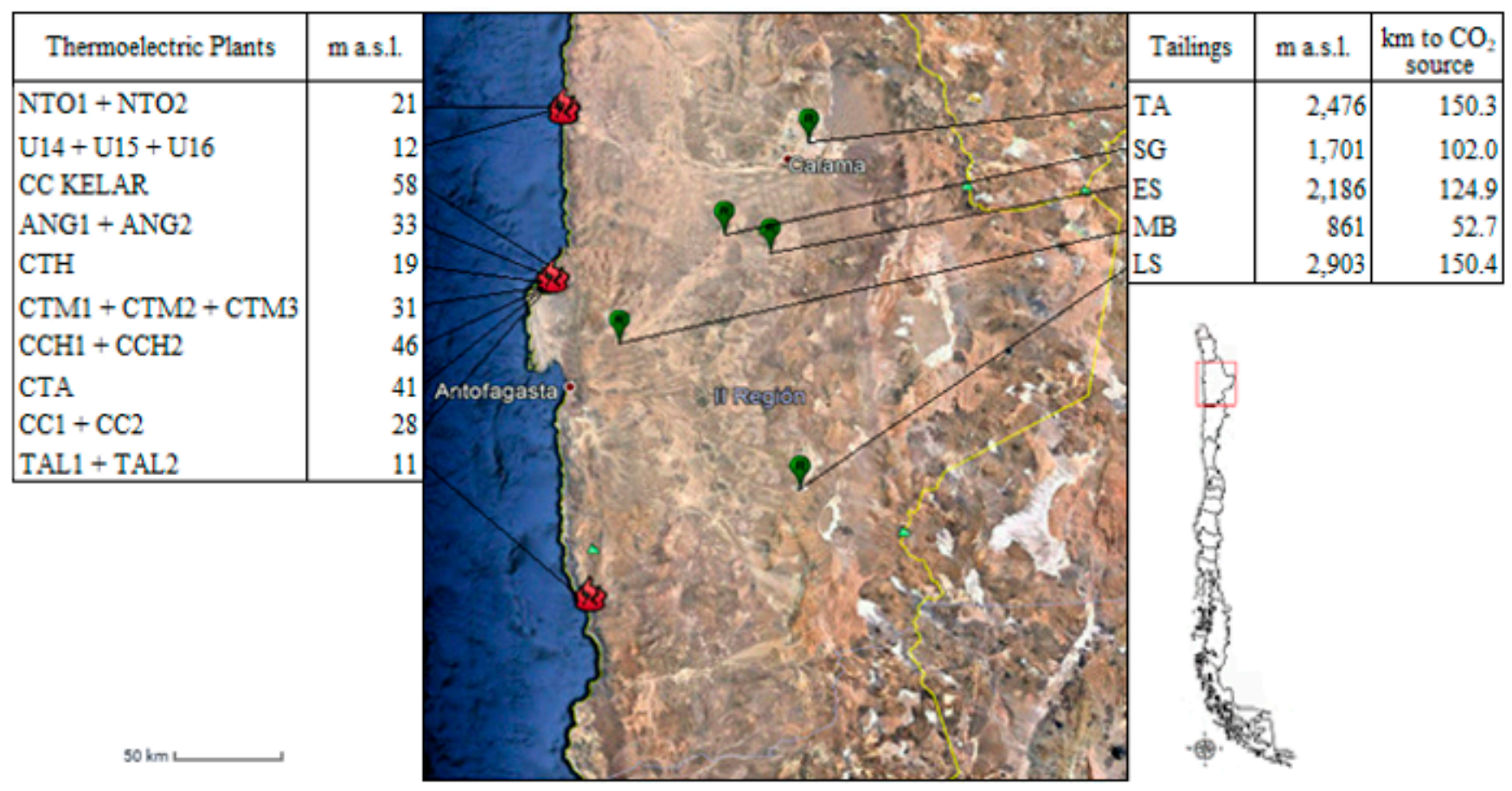

Figure 5. Location of thermoelectric plants and tailing deposits in the Antofagasta region. TA: Talabre tailing deposit; SG: Sierra Gorda tailing deposit; ES: Esperanza tailing deposit; MB: Mantos Blanco tailing deposit; LS: Laguna Seca tailing deposit; m.a.s.l: meters above sea level.

\section{Sensitivity Analysis}

The results for the closeness coefficient $\left(C C_{a}\right)$ of several tests are presented in Table S8 and were obtained by varying the criteria weights. Tests $\mathrm{T} 2$ to $\mathrm{T} 4$ consider the variation of $\mathrm{C} 1$ with increments of $25.0 \%, 37.5 \%$ and $50.0 \%$ in its value. The results showed that the method is more sensitive to criteria C4 and C5 since they generate the largest variation in the numerical results and consequently in the ranking order. However, the most critical criteria are those related to altitude (C7) and to distance (C8). In the case of liquid transport by pipelines, the difference in costs between the pumps for transporting water and carbon dioxide is negligible [72]. In the case of water transport, Zhou and Tol [73] determined that $100 \mathrm{~m}$ of vertical water transporting consumes the same energy as $100 \mathrm{~km}$ of horizontal water transporting. This energy consumption would considerably reduce the global efficiency of sequestration due to the $\mathrm{CO}_{2}$ generated by the transportation of $\mathrm{CO}_{2}$ from the thermoelectric plant to the tailing deposits. The deposit with the optimal values for these criteria is MB. The MB deposit was most frequently ranked first, at $43 \%$ of the times, whereas the Sierra Gorda (SG) deposit was most frequently ranked last at $36 \%$ of the times. The results obtained from the 28 tests are presented in Figure 6, in which the results are presented in unit area. As observed, MB covered $36.10 \%$ of the total area, whereas TA, LS, SG, and Esperanza (ES) covered $34.18 \%, 25.91 \%, 17.42 \%$, and $16.96 \%$, respectively. Therefore, the final decision is that the MB deposit can be selected as the most suitable site for the installation of a MC plant in Chile. 


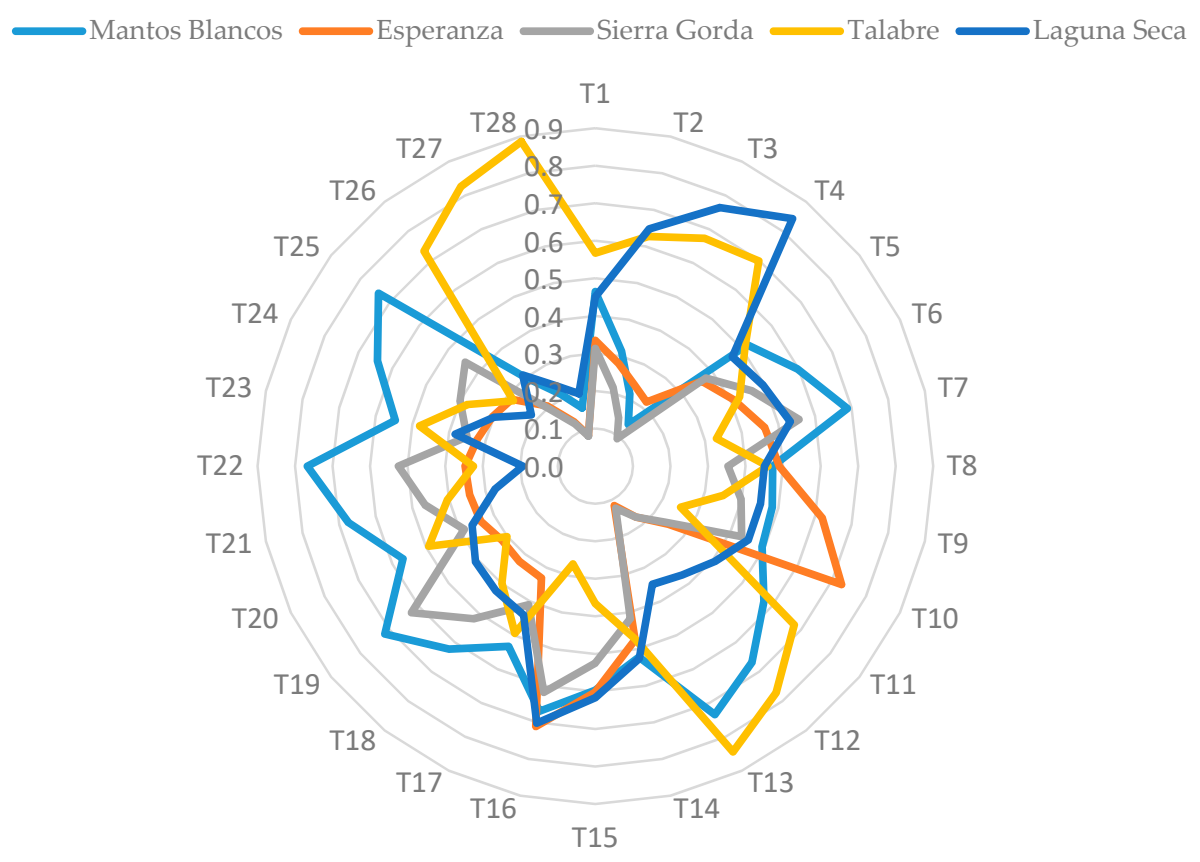

Figure 6. Main results obtained from the technique for order preference by similarity to ideal solution (TOPSIS) method application.

\section{Final Comments}

Carbon capture and storage is a key technology for mitigating $\mathrm{CO}_{2}$ emissions of anthropogenic origin, providing a method to achieve the transition from the use of energy produced by the burning of fossil fuels to increased usage of renewable energies to limit global warming below a threshold of $2{ }^{\circ} \mathrm{C}$, according to the existing treaties to which Chile is signatory, such as the Kioto Protocol, Montreal Protocol, Basel Convention, the United Nations Framework Convention on Climate Change, Antarctic Treaty, among others. Chile is sensitive to the effects of climate change throughout the country, starting from the south with glacier melting and rising sea levels, following in the center with lower rainfall and snow precipitation in the high mountains, and ending in the north with a higher frequency of dry days and longer heatwaves. In addition, it is seen that Chile has a regulatory framework that still has serious weaknesses in caring for the environment, in the case of thermoelectric plants without an emission limit for certain compounds, including $\mathrm{CO}_{2}$, while in the case of tailings deposits with scarce mineralogical data and lack of background metal concentrations data of soils, due to the large number of these.

However, in the north of Chile, the thermoelectric plants focused on producing electric power to support the demand required by the large amounts of mining in the region strongly depend on the burning of fossil fuels. The use of mining tailings for the sequestration of $\mathrm{CO}_{2}$ produced by the power plants is proposed as a feasible solution to meet Chile's aim of decarbonizing its energy matrix, as well as the generation of economic value through the recovery of valuable metals. This technology can be applied to sequester emissions from power generating plants and to emissions produced by other industries, such as the production of cement or lime, which occur in the same area. The sequestration could be completed using mining tailings as well as storing $\mathrm{CO}_{2}$ in a large number of saline aquifers existing in the region.

\section{Conclusions}

Following the discussion presented in this paper and the results presented in the preceding sections, the following main conclusions can be drawn: 
1. Mineral carbonation is a feasible solution for tackling the problem of the deposition of tailings produced by the large copper industry developed in the north of Chile, as well as a strategy to mitigate the $\mathrm{CO}_{2}$ emissions produced by many power plants that supply electric energy to the mining industry.

2. According to the proposed methodology, the region of Antofagasta is considered the best location for the installation of a future mineral carbonation plant as close to $3600 \mathrm{Mt}$ of mine tailings are found in five large active deposits of tailings, which together have the potential to sequester between 66.0 to $98.6 \mathrm{Mt}$ of $\mathrm{CO}_{2}$. In addition, 19 thermoelectric plants are in operation, which in 2018 produced about $9.4 \mathrm{Mt}$ of $\mathrm{CO}_{2}$ that is available to be sequestered, with a maximum generation potential of $21.9 \mathrm{Mt}$ of $\mathrm{CO}_{2 \mathrm{eq}}$ per year.

3. The results obtained when applying the method TOPSIS, in addition to the sensitivity analysis, showed that the mineral carbonation plant should be located close to the deposit of tailings from Mantos Blancos (MB), as it is located the shortest distance from the $\mathrm{CO}_{2}$ source and at a lower altitude. The $\mathrm{MB}$ deposit has the highest concentration of $\mathrm{Cu}$ and REE, which generates the highest amount of income potential per ton of tailing (124.35 USD/t of tailings).

4. The recovery of valuable species, such as $\mathrm{Cu}, \mathrm{TiO}_{2}$, and $\mathrm{REE}$, must occur during the pretreatment stage of the tailings and before the precipitation of carbonates stage.

5. The results obtained are preliminary and require technical and economic studies of the tailings selected as the most promising to sequester $\mathrm{CO}_{2}$.

Supplementary Materials: The following are available online at https:/ /www.mdpi.com/2075-163 X/11/3/320/s1, Sensitivity analysis results.

Author Contributions: Conceptualization, L.A.C., O.M. and J.O.V.; methodology, O.M. and J.O.V.; investigation, O.M. and J.O.V.; writing-original draft preparation, O.M. and J.O.V.; writing-review and editing, O.M., J.O.V., A.K., and L.A.C.; supervision, J.O.V., A.K., and L.A.C.; project administration, L.A.C.; funding acquisition, L.A.C. All authors have read and agreed to the published version of the manuscript.

Funding: This research was funded by the National Agency for Research and Development (ANID, Chile) through the Grant Proyecto Anillo ACM 170005, Fondecyt 1180826, and Grant 21181949.

Institutional Review Board Statement: Not applicable.

Informed Consent Statement: Not applicable.

Data Availability Statement: Not applicable.

Acknowledgments: The authors are grateful for the support of the National Agency for Research and Development (ANID, Chile) through the Grant Proyecto Anillo ACM 170005. The authors also thank the Departamento de Ingeniería Química y Procesos de Minerales, Facultad de Ingeniería, Universidad de Antofagasta (Chile) for permanent support. O. Marin thanks ANID for a scholarship in support of national doctoral studies (Grant 21181949) and Programa de Doctorado en Ingeniería de Procesos de Minerales of the Universidad de Antofagasta. L. Cisternas thanks the especial support of ANID for grant Fondecyt 1180826.

Conflicts of Interest: The authors declare no conflict of interest.

\section{Abbreviations}

$\begin{array}{ll}\text { Symbols } & \\ \alpha & \text { Alternative } \\ \mathrm{CC}_{\mathrm{a}} & \text { Closeness coefficient } \\ \mathrm{i} & \text { Criteria } \\ \mathrm{r}_{\mathrm{ia}} & \text { Normalization value } \\ \mathrm{T} & \text { Number of operation hours throughout the year }[8760 / \text { year }] \\ \mathrm{V}_{\mathrm{i}}^{-} & \text {Anti-ideal value } \\ \mathrm{V}_{\mathrm{i}}^{+} & \text {Ideal value }\end{array}$




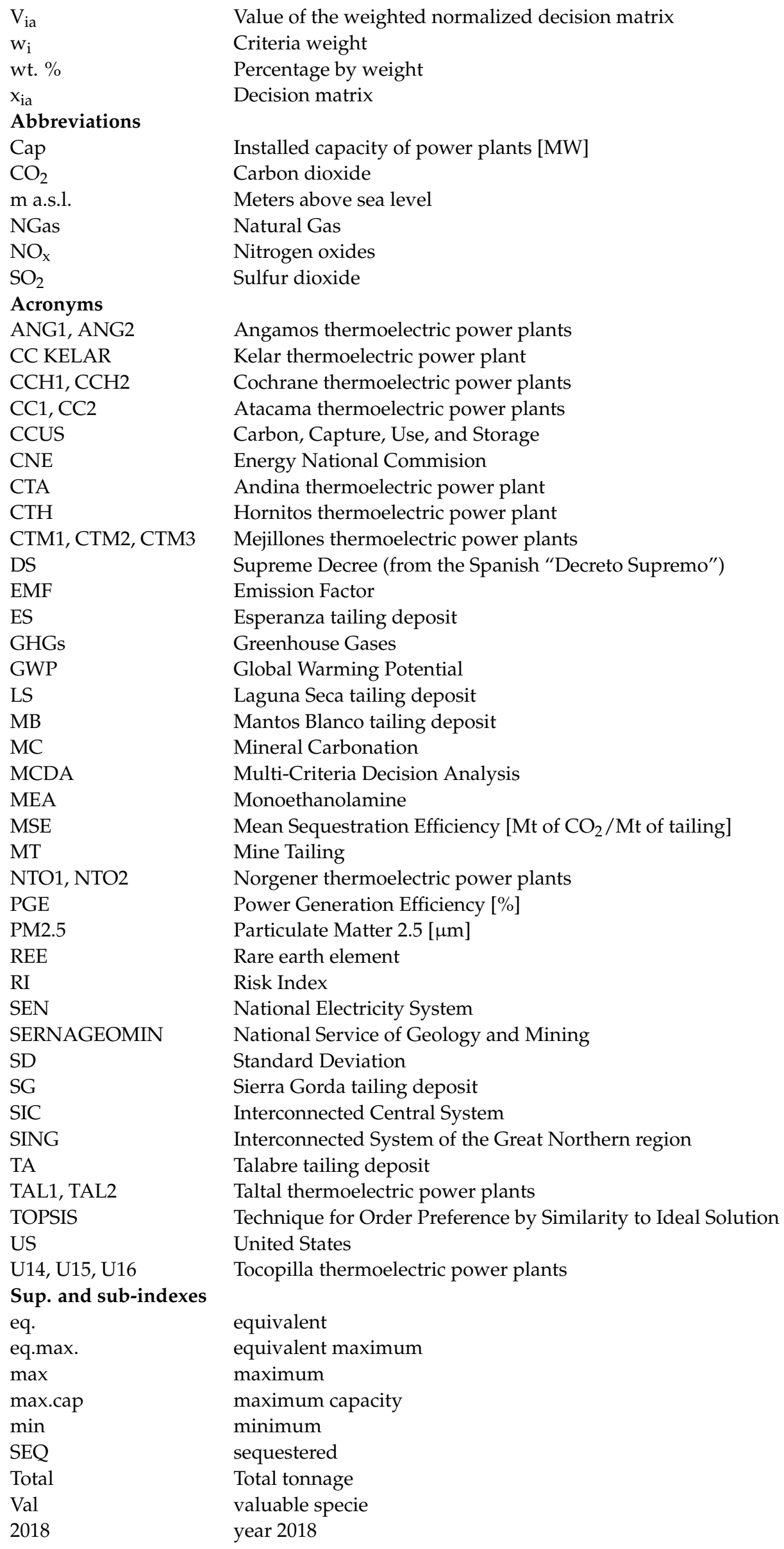




\section{References}

1. Stocker, T.F.; Qin, D.; Plattner, G.-K.; Tignor, M.; Allen, S.K.; Boschung, J.; Nauels, A.; Xia, Y.; Bex, V.; Midgley, P.M.; et al. Climate Change 2013: The Physical Science Basis: Working Group I Contribution to the Fifth Assessment Report of the Intergovernmental Panel on Climate Change; Cambridge University Press: Cambridge, UK, 2014.

2. IPCC. Climate Change 2007-The Physical Science Basis. Contribution of Working Group I to the Fourth Assessment Report of the IPCC; IPCC: Geneva, Switzerland, 2007; p. 996.

3. Hamilton, J.L.; Wilson, S.A.; Morgan, B.; Turvey, C.C.; Paterson, D.J.; Jowitt, S.M.; McCutcheon, J.; Southam, G. Fate of transition metals during passive carbonation of ultramafic mine tailings via air capture with potential for metal resource recovery. Int. J. Greenh. Gas Control. 2018, 71, 155-167. [CrossRef]

4. Shrestha, E.; Ahmad, S.; Johnson, W.; Shrestha, P.; Batista, J.R. Carbon footprint of water conveyance versus desalination as alternatives to expand water supply. Desalination 2011, 280, 33-43. [CrossRef]

5. Olajire, A.A. A review of mineral carbonation technology in sequestration of $\mathrm{CO}_{2}$. J. Pet. Sci. Eng. 2013, 109, 364-392. [CrossRef]

6. Edenhofer, O.; Pichs-Madruga, R.; Sokona, Y.; Farahani, E.; Kadner, S.; Seyboth, K.; Adler, A.; Baum, I.; Brunner, S.; Eickemeier, P.; et al. Climate Change 2014: Mitigation of Climate Change; Cambridge University Press: New York, NY, USA, 2014.

7. Surridge, A.; Cloete, M. Carbon capture and storage in South Africa. Energy Procedia 2009, 1, 2741-2744. [CrossRef]

8. Parsons Brinckerhoff and Global CCS Institute. Accelerating the Uptake of CCS: Industrial Use of Captured Carbon Dioxide; Parsons Brinckerhoff and Global CCS Institute: Melbourne, Australia, 2011.

9. Santos, R.M.; Bodor, M.; Dragomir, P.N.; Vraciu, A.G.; Vlad, M.; Van Gerven, T. Magnesium chloride as a leaching and aragonitepromoting self-regenerative additive for the mineral carbonation of calcium-rich materials. Miner. Eng. 2014, 59, 71-81. [CrossRef]

10. Sanna, A.; Uibu, M.; Caramanna, G.; Kuusik, R.; Maroto-Valer, M.M. A review of mineral carbonation technologies to sequester $\mathrm{CO}_{2}$. Chem. Soc. Rev. 2014, 43, 8049-8080. [CrossRef] [PubMed]

11. Seifritz, W. $\mathrm{CO}_{2}$ disposal by means of silicates. Nat. Cell Biol. 1990, 345, 486. [CrossRef]

12. Rackley, S. Carbon Capture and Storage; Butterworth-Heinemann: Amsterdam, The Netherlands, $2010 ;$ ISBN 9781856176361.

13. Bide, T.P.; Styles, M.T.; Naden, J. An assessment of global resources of rocks as suitable raw materials for carbon capture and storage by mineralisation. Appl. Earth Sci. 2014, 123, 179-195. [CrossRef]

14. Rahmani, O. $\mathrm{CO}_{2}$ sequestration by indirect mineral carbonation of industrial waste red gypsum. J. $\mathrm{CO}_{2}$ Util. 2018, 27, 374-380. [CrossRef]

15. Huijgen, W.J.J.; Comans, R.N.J. Carbon Dioxide Sequestration by Mineral Carbonation: Literature Review, ECN-C-03-016; Energy Research Centre of The Netherlands: Petten, The Netherlands, 2003.

16. Azdarpour, A.; Asadullah, M.; Mohammadian, E.; Hamidi, H.; Junin, R.; Karaei, M.A. A review on carbon dioxide mineral carbonation through pH-swing process. Chem. Eng. J. 2015, 279, 615-630. [CrossRef]

17. Gras, A.; Beaudoin, G.; Molson, J.; Plante, B. Atmospheric carbon sequestration in ultramafic mining residues and impacts on leachate water chemistry at the Dumont Nickel Project, Quebec, Canada. Chem. Geol. 2020, 546, 119661. [CrossRef]

18. Hamilton, J.L.; Wilson, S.A.; Morgan, B.; Harrison, A.L.; Turvey, C.C.; Paterson, D.J.; Dipple, G.M.; Southam, G. Accelerating Mineral Carbonation in Ultramafic Mine Tailings via Direct $\mathrm{CO}_{2}$ Reaction and Heap Leaching with Potential for Base Metal Enrichment and Recovery. Econ. Geol. 2020, 115, 303-323. [CrossRef]

19. Li, J.; Hitch, M.; Power, I.M.; Pan, Y. Integrated Mineral Carbonation of Ultramafic Mine Deposits-A Review. Minerials 2018, 8, 147. [CrossRef]

20. Hills, C.D.; Tripathi, N.; Carey, P.J. Mineralization Technology for Carbon Capture, Utilization, and Storage. Front. Energy Res. 2020, 8, 8. [CrossRef]

21. Penner, L.R.; O'Connor, W.K.; Dahlin, D.C.; Gerdemann, S.J.; Rush, G.E. Mineral Carbonation: Energy Costs of Pretreatment Options and Insights Gained from Flow Loop Reaction Studies; International Atomic Energy Agency (IAEA): Vienna, Austria, 2004.

22. Araya, N.; Kraslawski, A.; Cisternas, L.A. Towards mine tailings valorization: Recovery of critical materials from Chilean mine tailings. J. Clean. Prod. 2020, 263, 121555. [CrossRef]

23. Araya, N.; Ramírez, Y.; Kraslawski, A.; Cisternas, L.A. Feasibility of re-processing mine tailings to obtain critical raw materials using real options analysis. J. Environ. Manag. 2021, 284, 112060. [CrossRef] [PubMed]

24. Rajagopal, S.; Ng, K.; Douglas, J. A hierarchical procedure for the conceptual design of solids processes. Comput. Chem. Eng. 1992, 16, 675-689. [CrossRef]

25. Cisternas, L.A.; Lucay, F.; Gálvez, E.D. Effect of the objective function in the design of concentration plants. Miner. Eng. 2014, 63, 16-24. [CrossRef]

26. Kularatne, K.; Sissmann, O.; Kohler, E.; Chardin, M.; Noirez, S.; Martinez, I. Simultaneous ex-situ $\mathrm{CO}_{2}$ mineral sequestration and hydrogen production from olivine-bearing mine tailings. Appl. Geochem. 2018, 95, 195-205. [CrossRef]

27. Sugama, T.; Ecker, L.; Butcher, T. Carbonation of Rock Minerals by Supercritical Carbon Dioxide at $250{ }^{\circ} \mathrm{C}$; Brookhaven National Lab. (BNL): Upton, NY, USA, 2010.

28. Martín, D.; Aparicio, P.; Galán, E. Mineral carbonation of ceramic brick at low pressure and room temperature. A simulation study for a superficial $\mathrm{CO}_{2}$ store using a common clay as sealing material. Appl. Clay Sci. 2018, 161, 119-126. [CrossRef]

29. Haug, T.; Munz, I.; Kleiv, R. Importance of dissolution and precipitation kinetics for mineral carbonation. Energy Procedia 2011, 4 , 5029-5036. [CrossRef] 
30. Paukert, A.N.; Matter, J.M.; Kelemen, P.B.; Shock, E.L.; Havig, J.R. Reaction path modeling of enhanced in situ $\mathrm{CO}_{2}$ mineralization for carbon sequestration in the peridotite of the Samail Ophiolite, Sultanate of Oman. Chem. Geol. 2012, 330-331, 86-100. [CrossRef]

31. Murugan, A.; Brown, R.J.C.; Wilmot, R.; Hussain, D.; Bartlett, S.; Brewer, P.J.; Worton, D.R.; Bacquart, T.; Gardiner, T.; Robinson, R.A.; et al. Performing Quality Assurance of Carbon Dioxide for Carbon Capture and Storage. Carbon Res. 2020, 6, 76. [CrossRef]

32. Olajire, A.A. $\mathrm{CO}_{2}$ capture and separation technologies for end-of-pipe applications-A review. Energy 2010, 35, 2610-2628. [CrossRef]

33. Pasquier, L.-C.; Mercier, G.; Blais, J.-F.; Cecchi, E.; Kentish, S. Parameters optimization for direct flue gas $\mathrm{CO}_{2}$ capture and sequestration by aqueous mineral carbonation using activated serpentinite based mining residue. Appl. Geochem. 2014, 50, 66-73. [CrossRef]

34. Meyer, N.; Vögeli, J.; Becker, M.; Broadhurst, J.; Reid, D.; Franzidis, J.-P. Mineral carbonation of PGM mine tailings for $\mathrm{CO}_{2}$ storage in South Africa: A case study. Miner. Eng. 2014, 59, 45-51. [CrossRef]

35. Boschi, C.; Bedini, F.; Baneschi, I.; Rielli, A.; Baumgartner, L.; Perchiazzi, N.; Ulyanov, A.; Zanchetta, G.; Dini, A. Spontaneous Serpentine Carbonation Controlled by Underground Dynamic Microclimate at the Montecastelli Copper Mine, Italy. Minerials 2019, 10, 1. [CrossRef]

36. Andreoli, E. Materials and Processes for Carbon Dioxide Capture and Utilisation. Carbon Res. 2017, 3, 16. [CrossRef]

37. Ghiat, I.; Al-Ansari, T. A review of carbon capture and utilisation as a $\mathrm{CO}_{2}$ abatement opportunity within the $\mathrm{EWF}$ nexus. J. $\mathrm{CO}$ Util. 2021, 45, 101432. [CrossRef]

38. Giannoulakis, S.; Volkart, K.; Bauer, C. Life cycle and cost assessment of mineral carbonation for carbon capture and storage in European power generation. Int. J. Greenh. Gas Control. 2014, 21, 140-157. [CrossRef]

39. Yong, D. Plant location selection based on fuzzy TOPSIS. Int. J. Adv. Manuf. Technol. 2006, 28, 839-844. [CrossRef]

40. Behzadian, M.; Otaghsara, S.K.; Yazdani, M.; Ignatius, J. A state-of the-art survey of TOPSIS applications. Expert Syst. Appl. 2012, 39, 13051-13069. [CrossRef]

41. Chu, T.-C.; Lin, Y.-C. An interval arithmetic based fuzzy TOPSIS model. Expert Syst. Appl. 2009, 36, 10870-10876. [CrossRef]

42. Ertuğrul, I. Fuzzy Group Decision Making for the Selection of Facility Location. Gr. Decis. Negot. 2011, 20, 725-740. [CrossRef]

43. Wang, Y.-J. Fuzzy multi-criteria decision-making based on positive and negative extreme solutions. Appl. Math. Model. 2011, 35, 1994-2004. [CrossRef]

44. Safari, M.; Kakaei, R.; Ataei, M.; Karamoozian, M. Using fuzzy TOPSIS method for mineral processing plant site selection: Case study: Sangan iron ore mine (phase 2). Arab. J. Geosci. 2012, 5, 1011-1019. [CrossRef]

45. Araya, N.; Lucay, F.A.; Cisternas, L.A.; Gálvez, E.D. Design of Desalinated Water Distribution Networks: Complex Topography, Energy Production, and Parallel Pipelines. Ind. Eng. Chem. Res. 2018, 57, 9879-9888. [CrossRef]

46. Juan Ocaranza, A. Cochilco Anuario de Estadisticas del Cobre y Otros Minerales 1999-2018; The Chilean Copper Commission: Santiago, Chile, 2019.

47. González, C.C. Cochilco Inversión en la Minería Chilena. Cartera de Proyectos 2017-2026; The Chilean Copper Commission: Santiago, Chile, 2017.

48. SERNAGEOMIN. Datos Públicos Depósito de Relaves. 2019. Available online: https://www.sernageomin.cl/datos-publicosdeposito-de-relaves (accessed on 3 November 2019).

49. Park, J.; Yang, M.; Kim, S.; Lee, M.; Wang, S. Estimates of $\mathrm{scCO}_{2}$ Storage and Sealing Capacity of the Janggi Basin in Korea Based on Laboratory Scale Experiments. Minerials 2019, 9, 515. [CrossRef]

50. Lam, E.J.; Montofré, I.L.; Álvarez, F.A.; Gaete, N.F.; Poblete, D.A.; Rojas, R.J. Methodology to Prioritize Chilean Tailings Selection, According to Their Potential Risks. Int. J. Environ. Res. Public Health 2020, 17, 3948. [CrossRef]

51. Vogeli, J.; Reid, D.; Becker, M.; Broadhurst, J.; Franzidis, J.-P. Investigation of the potential for mineral carbonation of PGM tailings in South Africa. Miner. Eng. 2011, 24, 1348-1356. [CrossRef]

52. Lam, E.J.; Zetola, V.; Ramírez, Y.; Montofré, Í.L.; Pereira, F. Making Paving Stones from Copper Mine Tailings as Aggregates. Int. J. Environ. Res. Public Health 2020, 17, 2448. [CrossRef]

53. Tripodi, E.E.M.; Rueda, J.A.G.; Céspedes, C.A.; Vega, J.D.; Gomez, C.C. Characterization and geostatistical modelling of contaminants and added value metals from an abandoned $\mathrm{Cu}-\mathrm{Au}$ tailing dam in Taltal (Chile). J. South Am. Earth Sci. 2019, 93, 183-202. [CrossRef]

54. Cortés, S.; Soto, E.E.; Ordóñez, J.I. Recovery of Copper from Leached Tailing Solutions by Biosorption. Minerials 2020, 10, 158. [CrossRef]

55. Drobe, M.; Haubrich, F.; Gajardo, M.; Marbler, H. Processing Tests, Adjusted Cost Models and the Economies of Reprocessing Copper Mine Tailings in Chile. Metals 2021, 11, 103. [CrossRef]

56. Smuda, J.; Dold, B.; Spangenberg, J.E.; Pfeifer, H.-R. Geochemistry and stable isotope composition of fresh alkaline porphyry copper tailings: Implications on sources and mobility of elements during transport and early stages of deposition. Chem. Geol. 2008, 256, 62-76. [CrossRef]

57. Dold, B.; Fontboté, L. Element cycling and secondary mineralogy in porphyry copper tailings as a function of climate, primary mineralogy, and mineral processing. J. Geochem. Explor. 2001, 74, 3-55. [CrossRef]

58. CNE. CNE Reporte Capacidad Instalada Generación Marzo de 2019; Comisión Nacional de Energía: Santiago, Chile, 2019. 
59. BCN. Decreto Supremo 13, de 2011, Norma de Emisión para Centrales Termoeléctricas. Available online: https:/ /www.bcn.cl/ leychile/navegar?idNorma $=1026808$ (accessed on 10 August 2020).

60. Hwang, C.; Yoon, K. Multiple Attributes Decision Making: Methods and Applications; Springer: Berlin/Heidelberg, Germany; New York, NY, USA, 1981.

61. SONAMI. Valorización de Relaves de la Mediana Minería. Sociedad Nacional de Minería. Available online: https:/ www.sonami. cl/v2/wp-content/uploads/2016/03/10.-Valorizacion-de-Relaves-de-la-Mediana-Mineria.pdf (accessed on 15 January 2021).

62. Bui, M.; Adjiman, C.S.; Bardow, A.; Anthony, E.J.; Boston, A.; Brown, S.; Fennell, P.S.; Fuss, S.; Galindo, A.; Hackett, L.A.; et al. Carbon capture and storage (CCS): The way forward. Energy Environ. Sci. 2018, 11, 1062-1176. [CrossRef]

63. McCoy, S.T.; Rubin, E.S. An engineering-economic model of pipeline transport of $\mathrm{CO}_{2}$ with application to carbon capture and storage. Int. J. Greenh. Gas Control. 2008, 2, 219-229. [CrossRef]

64. Koornneef, J.; Spruijt, M.; Molag, M.; Ramírez, A.; Turkenburg, W.; Faaij, A. Quantitative risk assessment of $\mathrm{CO}_{2}$ transport by pipelines-A review of uncertainties and their impacts. J. Hazard. Mater. 2010, 177, 12-27. [CrossRef]

65. Karimi, M.; Hillestad, M.; Svendsen, H.F. Capital costs and energy considerations of different alternative stripper configurations for post combustion $\mathrm{CO}_{2}$ capture. Chem. Eng. Res. Des. 2011, 89, 1229-1236. [CrossRef]

66. Valderrama, J.O.; Campusano, R.; Espindola, C. Minería Chilena: Captura, Transporte, y Almacenamiento de Dióxido de Carbono en Relaves mediante Líquidos Iónicos y Carbonatación Mineral. Inf. Tecnol. 2019, 30, 357-372. [CrossRef]

67. Mena, S.; Guirado, G. Electrochemical Tuning of $\mathrm{CO}_{2}$ Reactivity in Ionic Liquids Using Different Cathodes: From Oxalate to Carboxylation Products. Carbon Res. 2020, 6, 34. [CrossRef]

68. Northey, S.; Haque, N.; Mudd, G. Using sustainability reporting to assess the environmental footprint of copper mining. J. Clean. Prod. 2013, 40, 118-128. [CrossRef]

69. Khoo, Z.-Y.; Ho, E.H.Z.; Li, Y.; Yeo, Z.; Low, J.S.C.; Bu, J.; Chia, L.S.O. Life cycle assessment of a $\mathrm{CO}_{2}$ mineralisation technology for carbon capture and utilisation in Singapore. J. $\mathrm{CO}_{2}$ Util. 2021, 44, 101378. [CrossRef]

70. Yu, P. Carbon tax/subsidy policy choice and its effects in the presence of interest groups. Energy Policy 2020, 147, 111886. [CrossRef]

71. Stolaroff, J.K.; Lowry, G.V.; Keith, D.W. Using CaO- and MgO-rich industrial waste streams for carbon sequestration. Energy Convers. Manag. 2005, 46, 687-699. [CrossRef]

72. Knoope, M.; Guijt, W.; Ramírez, A.; Faaij, A. Improved cost models for optimizing $\mathrm{CO}_{2}$ pipeline configuration for point-to-point pipelines and simple networks. Int. J. Greenh. Gas Control. 2014, 22, 25-46. [CrossRef]

73. Zhou, Y.; Tol, R.S.J. Evaluating the costs of desalination and water transport. Water Resour. Res. 2005, 41, 1-10. [CrossRef] 